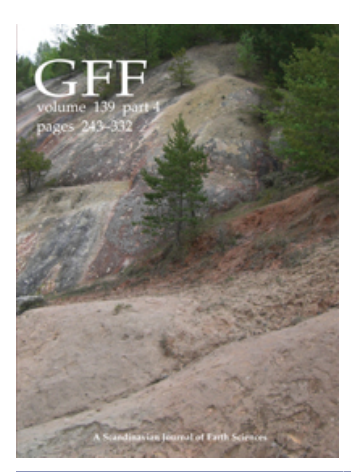

GFF

\title{
The South Swedish Dome: a key structure for identification of peneplains and conclusions on Phanerozoic tectonics of an ancient shield
}

\section{Karna Lidmar-Bergström, Mats Olvmo \& Johan M. Bonow}

To cite this article: Karna Lidmar-Bergström, Mats Olvmo \& Johan M. Bonow (2017) The South Swedish Dome: a key structure for identification of peneplains and conclusions on Phanerozoic tectonics of an ancient shield, GFF, 139:4, 244-259, DOI: 10.1080/11035897.2017.1364293

To link to this article: https://doi.org/10.1080/11035897.2017.1364293

\section{曲 Published online: 30 Aug 2017.}

Submit your article to this journal $\pi$
III Article views: 326

Q View related articles $匚$

View Crossmark data $\nearrow$

Citing articles: 4 View citing articles $\longleftarrow$ 


\title{
The South Swedish Dome: a key structure for identification of peneplains and conclusions on Phanerozoic tectonics of an ancient shield
}

\author{
Karna Lidmar-Bergströma ${ }^{a}$, Mats Olvmo ${ }^{b}$ and Johan M. Bonow ${ }^{c, d}$ \\ aDepartment of Physical Geography, Stockholm University, Stockholm, Sweden; 'Department of Earth Sciences, Gothenburg University, Göteborg, \\ Sweden; 'Department of Tourism Studies and Geography, Mid Sweden University, Östersund, Sweden; dGeovisiona AB, Järfälla, Sweden
}

\begin{abstract}
The relationships between different denudation surfaces/peneplains formed across crystalline basement rocks give valuable information to the tectonic development of ancient shields. The denudation surfaces can be identified by the aid of their landforms, tilt and remnant weathering mantles in relation to cover rocks. Three types of denudation surfaces are identified across south Sweden (1) a tilted flat plain, (2) a tilted hilly surface with relative relief below $150 \mathrm{~m}$ and (3) stepped horizontal plains with residual hills. All three types of denudation surfaces are peneplains, denudation surfaces graded to specific base levels. The re-exposed parts of the inclined flat sub-Cambrian peneplain (SCP) extend as a landscape feature from below cover rocks in the north and east and reaches up on the highest summits of the South Swedish Uplands. The SCP (the exact unconformity) is encountered again below Cambrian covers outside the west coast. Thus south Sweden is a geological dome, the South Swedish Dome (SSD), in relation to the Cambrian cover. The southern and western low flanks of the exposed part of the dome are instead characterized by a hilly peneplain, the inclined sub-Cretaceous denudation surface, with remnants of thick, kaolinitic, clayey saprolites. This sub-Cretaceous peneplain is cut off at a distinct level in the south and west by the almost horizontal South Småland Peneplain, a never covered, epigene, peneplain. The uplift history of the SSD aids to the understanding on the development of late Tertiary drainage systems of the Baltic Basin by the Eridano River.
\end{abstract}

ARTICLE HISTORY

Received 24 February 2017

Accepted 31 July 2017

\section{KEYWORDS}

Denudation surface; peneplain; relief differentiation; saprolite; remnants of cover rocks; uplift; tectonics

\section{Introduction}

The relief of the South Swedish Uplands (a geographical term) was described by Rudberg (1960, 1970), who also summarized (1970) interpretations made by early geologists and geomorphologists. Lidmar-Bergström (1982, 1988, 1994, 1995, 1996) identified denudation surfaces across the basement rocks by the aid of their landforms, tilt and remnant weathering mantles in relation to cover rocks. These investigations showed that the South Swedish Uplands constitute a geological dome, the South Swedish Dome (SSD) (Lidmar-Bergström 1988, 1996) in relation to the Cambrian cover.

The SSD gives a unique possibility to define re-exposed denudation surfaces with different kinds of relief and their crosscutting relationships to surfaces that have remained uncovered since the start of their formation (epigene surfaces). We here demonstrate how the denudation surfaces were identified and then were used to reveal Phanerozoic tectonic movements of an area mainly underlain by Precambrian rocks. This paper mainly reviews earlier studies. It first reviews those written by Rudberg for geographers. The main part of the paper defines the special conditions on a shield with periods of erosion and periods of covering, shows how relief and saprolites can be used to define old denudation surfaces by reviewing earlier studies of the SSD and with adding of some new data. We also show how the late
Cenozoic uplift history of the SSD aids to the understanding on the development of late Tertiary drainage systems of the Baltic Basin by the Eridano River.

\section{Early descriptions and interpretations of the bedrock morphology of southern Sweden}

Before the geological SSD (location shown in Fig. 1) was identified, there were several descriptions of its large-scale landforms. Rudberg $(1960,1970)$ summarized the knowledge about major landforms in Sweden and made an objective description of morphological regions of southern Sweden (based on detailed analysis of topographic maps, Generalstabskartan in 1:50 000) including the following groups (Fig. 2A): (1) plains with relative heights of up to $20 \mathrm{~m}$, (2) fissure valley landscapes (Swedish sprickdalslandskap; landscapes with joint-aligned valleys acc. to Lidmar-Bergström 1995), (3-5) undulating hilly land (Swedish bergkullterräng) with relative heights 20 to $>100 \mathrm{~m}$, (6) monadnock plains (Swedish bergkullslätter) in a NW-SE zone in central Småland. This is a reliable description of landscape forms.

An interpretation of the morphological regions was presented by Rudberg (1960), summarizing earlier published interpretations of the landforms as belonging to different peneplains, by then thought to have been formed entirely by fluvial erosion 


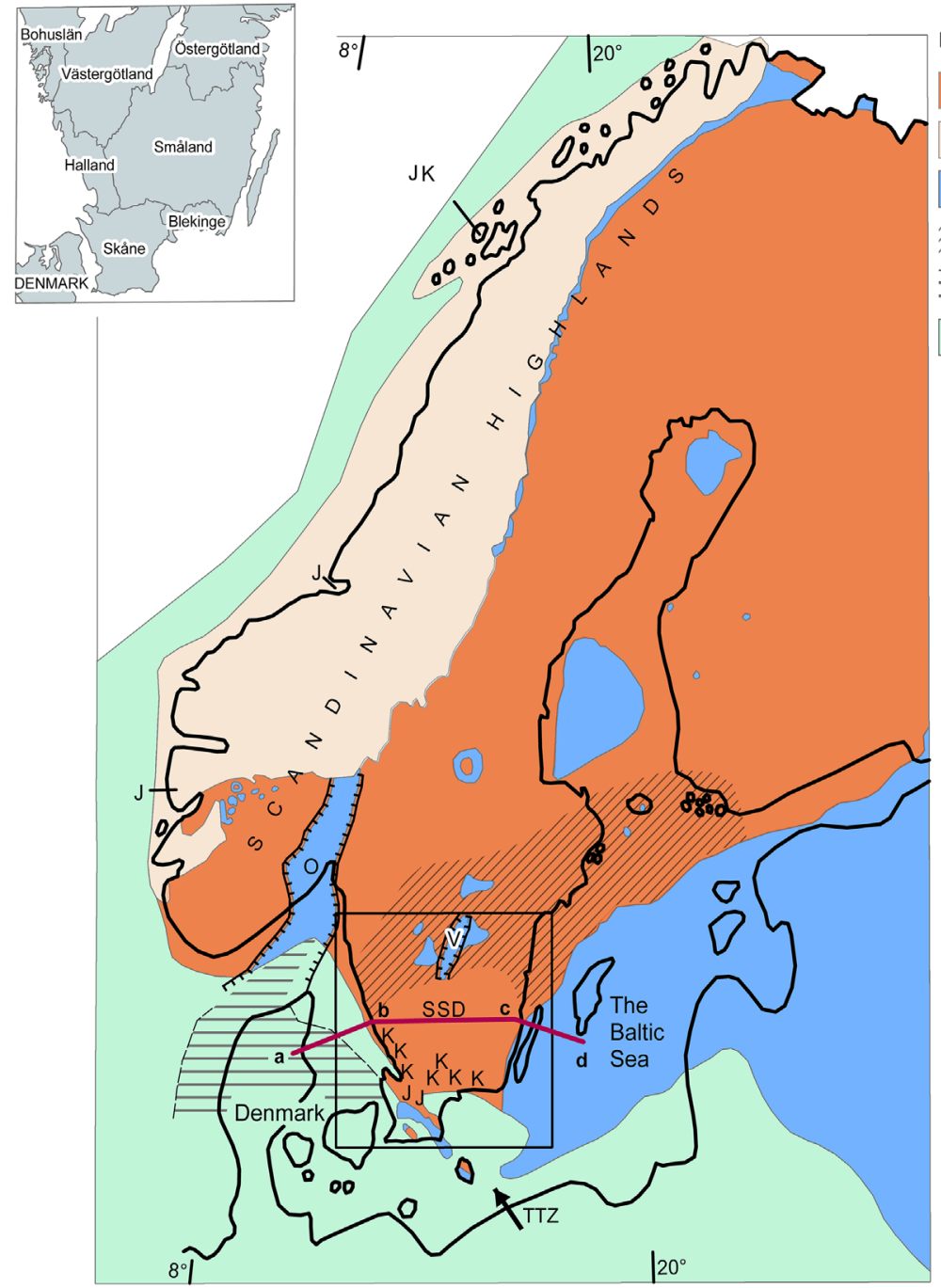

Bedrock

A

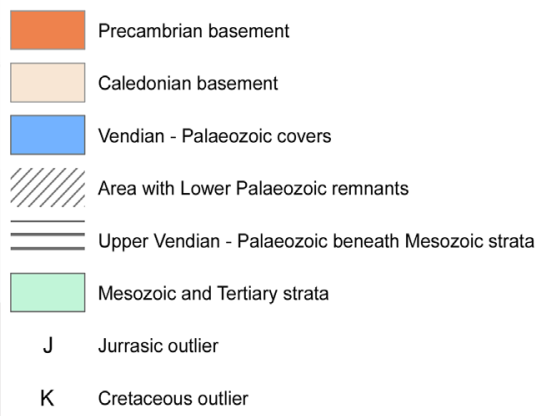

\section{Structures}

$\longrightarrow$ TTZ Tornquist Tectonic Zone

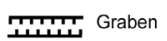

O Oslo Graben

V Vätter Graben

SSD South Swedish Dome
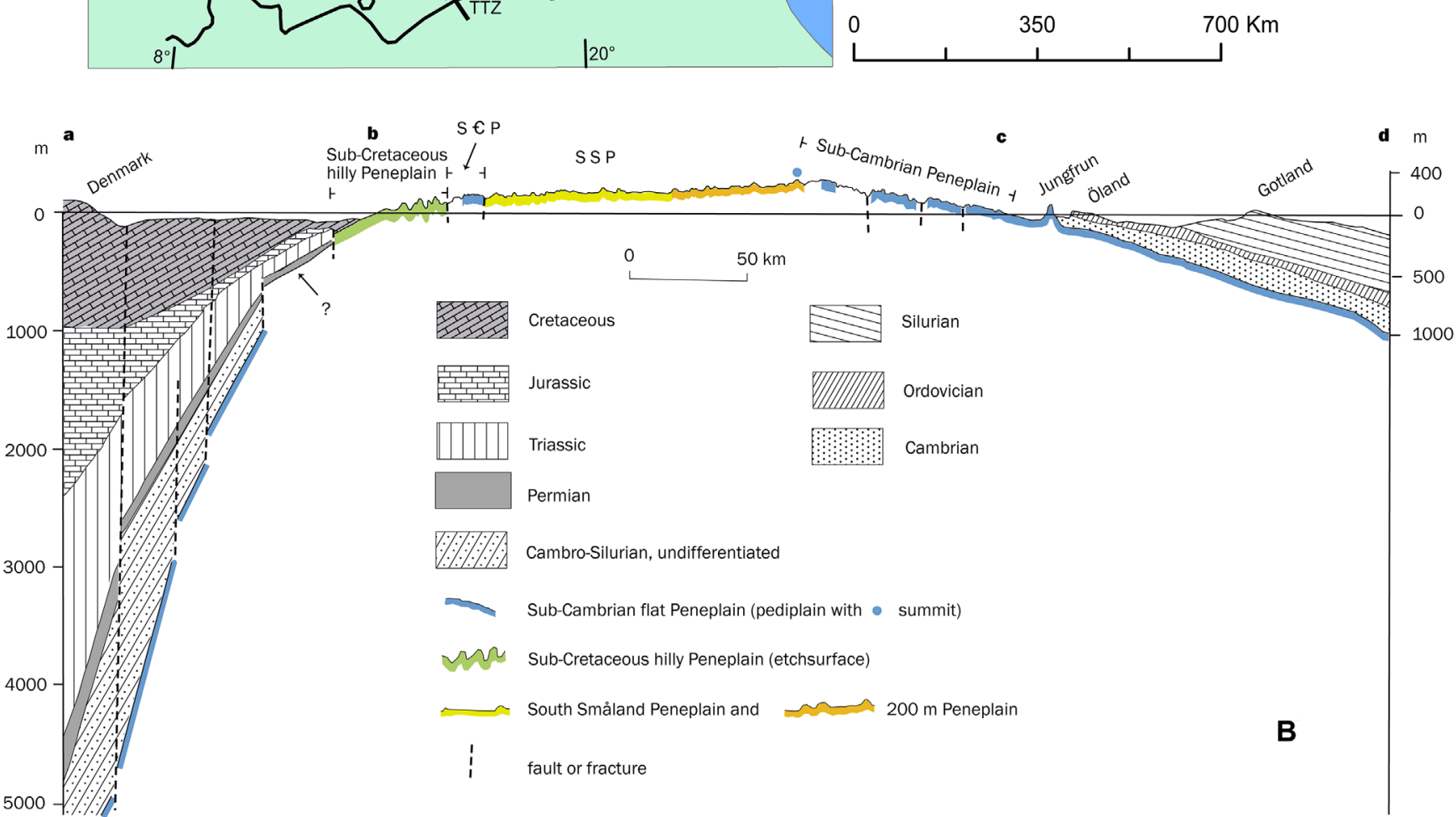

Figure 1. Scandinavia, basement and cover rocks. A. Map of Scandinavia with basement and cover rocks. Modified from Lidmar-Bergström et al. (1999). The square denotes approximately the South Swedish Dome (SSD). Profile Fig. 1B and maps Figs. 2, 4A and 5 are marked. B. Geologic profile from Denmark, over SSD, and to Gotland showing the relationships between basement peneplains and cover rocks. Modified from Kornfält \& Larsson (1987), Lidmar-Bergström (1996) and with information from Vejbæk (1997). 


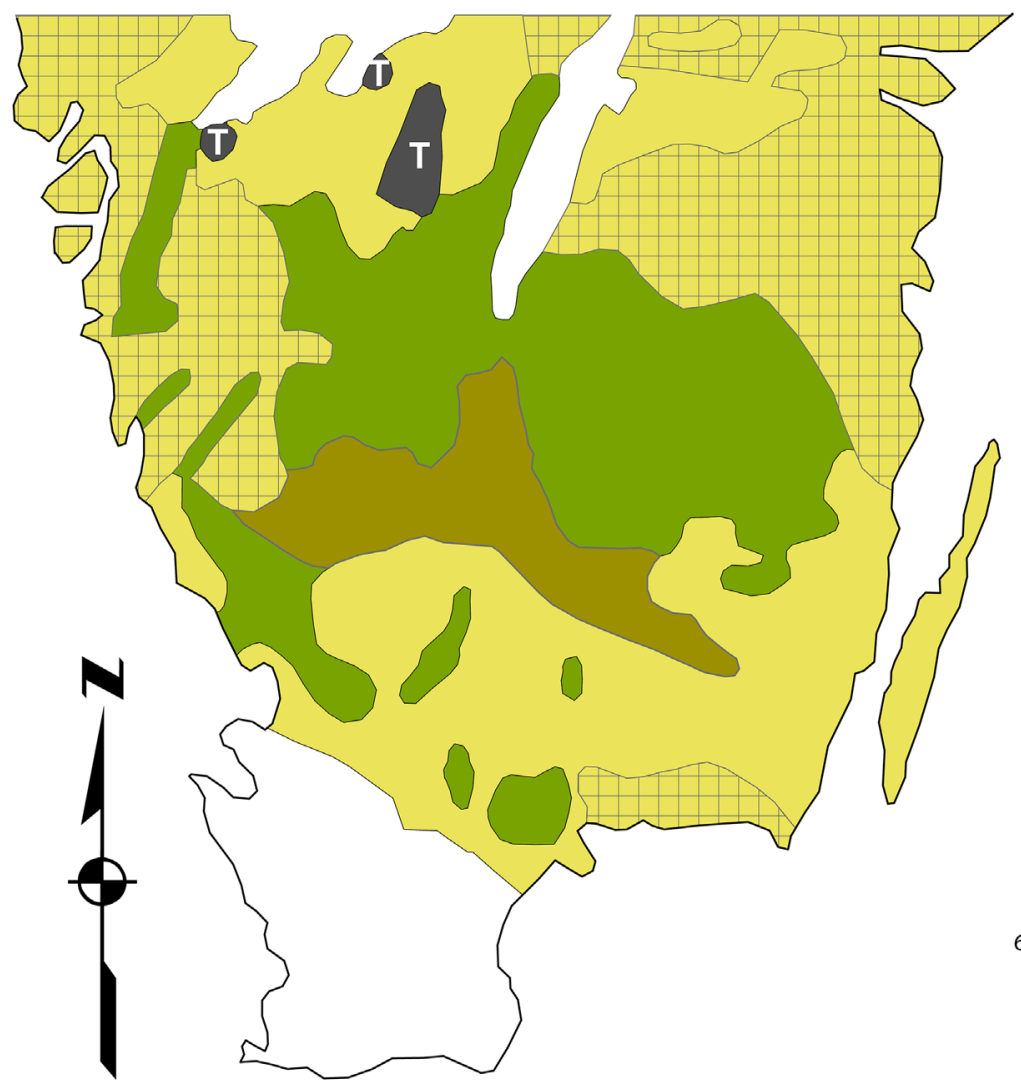

A
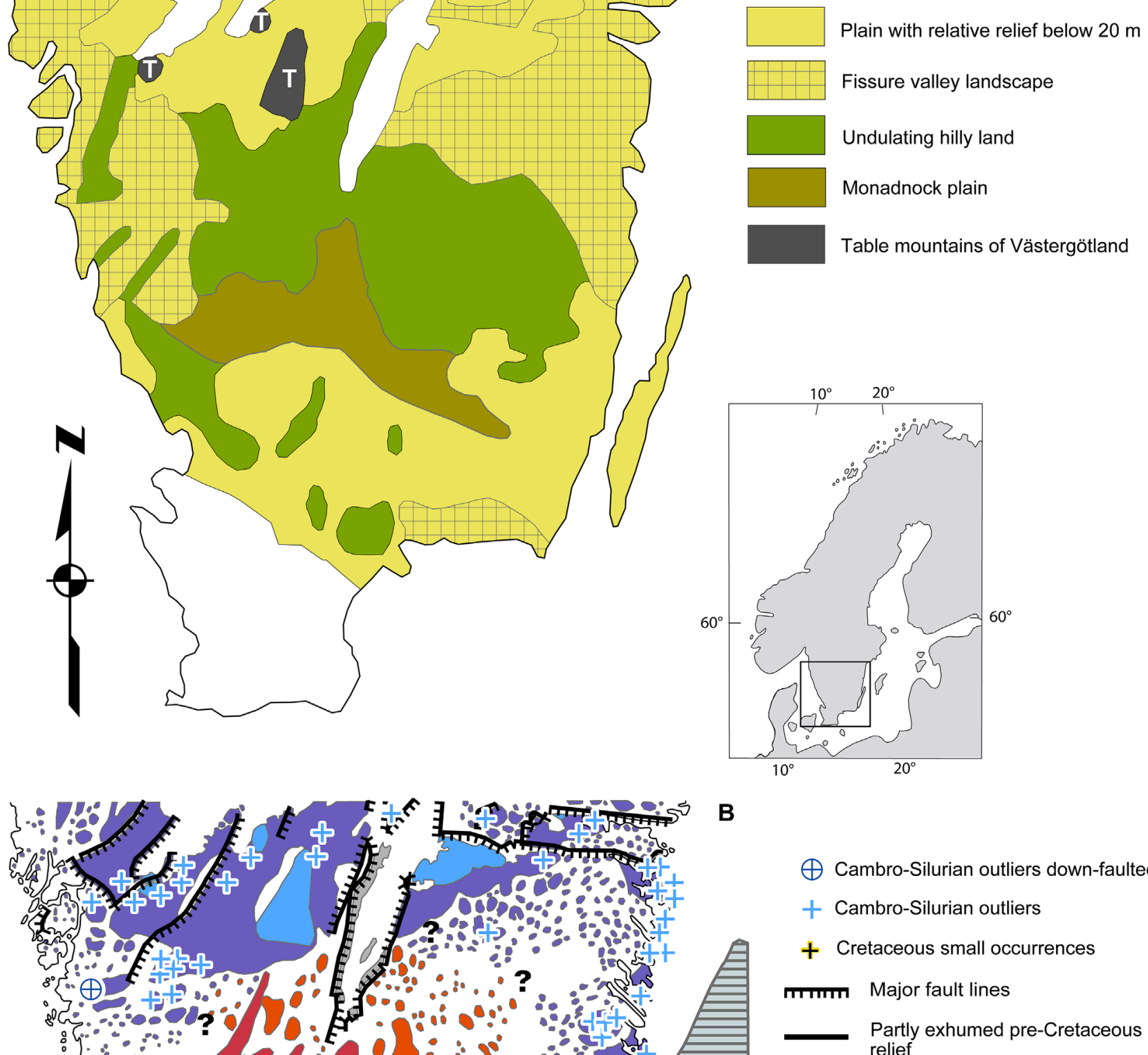

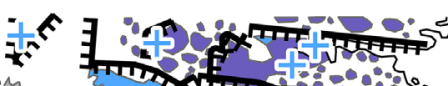

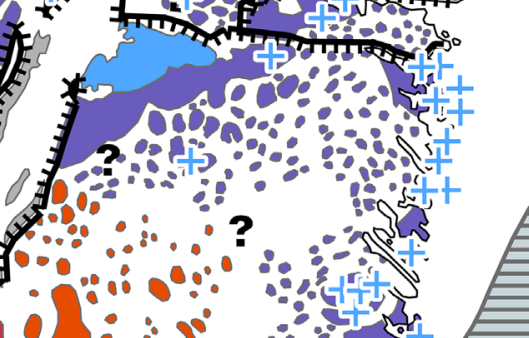

B

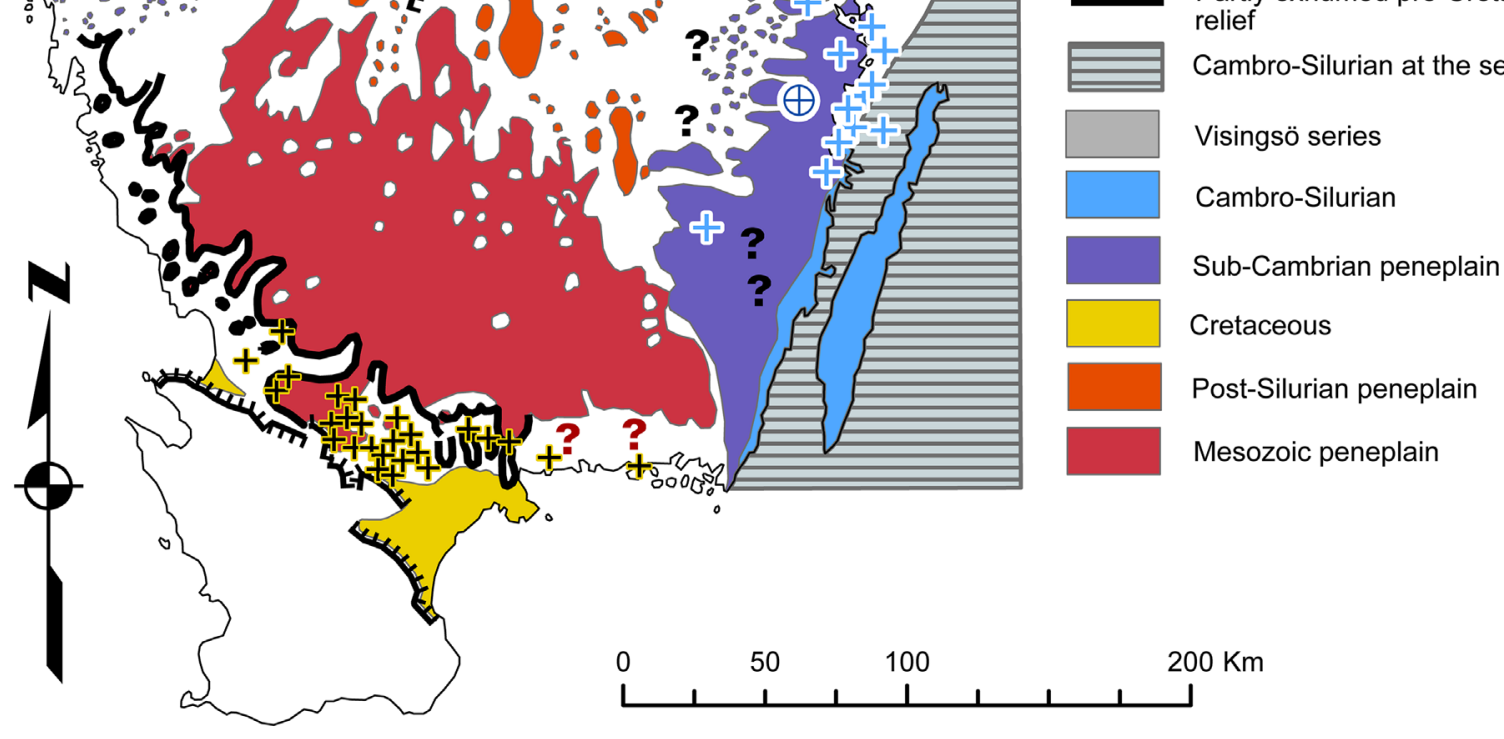

Figure 2. Geomorphology of southern Sweden from Rudberg (1970). A. Geomorphological type regions. B. Peneplains and cyclical denudation surfaces. For location see Fig. 1. Permission to use the maps by Rudberg (1970) is given by Svenska Sällskapet för Geografi och Antropologi 20 February 2017. 
to a base level (Fig. 2B). The interpretation was based on (1) the understanding of the relationships between the relief of the Precambrian basement and its Cambrian and Cretaceous cover rocks as described by geologists (e.g. Asklund 1928) and (2) the idea of peneplains appearing in a stepped sequence (Penck 1924; Braun 1935; Rudberg 1954). Information on Cambrian fissure fillings, mainly from the descriptions by the Swedish Geological Survey, were gathered and marked on his map. The map by Rudberg (1970) includes preserved parts of the sub-Cambrian flat peneplain, once identified by Högbom (1910). On this map, Rudberg put question marks on the sub-Cambrian peneplain (SCP) in SE Småland. Another peneplain is mapped at about $300 \mathrm{~m}$ a.s.l. and interpreted as a post-Silurian peneplain, as it is horizontal and cuts off the inclined SCP. A major and flat denudation surface had been identified across southwestern Småland by De Geer (1913). It was looked upon as a step below the $300 \mathrm{~m}$ peneplain by Rudberg (1970) and was labeled a Mesozoic peneplain (cf. Asklund 1928) as it was thought to continue from below Upper Cretaceous remnants in northern Skåne. The hilly relief in northeast Skåne and along the Halland coast was interpreted as partly exhumed (re-exposed) pre-Cretaceous relief, as it exists in connection with Cretaceous deposits.

Comparing his two maps, the descriptive map (Rudberg 1960; Fig. 2A) and the map of interpretation (Rudberg 1970; Fig. 2B), gives the following result.

The plain in southern Småland embraces both an area interpreted as the SCP in the east (but with question marks) and the low parts of the area interpreted as a Mesozoic peneplain step in the west. The plain mapped in the Östergötland area covers both a sedimentary plain of Cambro-Silurian strata and an area interpreted as the SCP. The plain mapped in northern Västergötland is identical with the area interpreted as the SCP.

The fissure valley landscape of NE Småland and adjacent parts of Östergötland coincide with areas where the SCP is interpreted to be in the summits. The fissure valley landscape in northern Halland, Bohuslän and adjacent parts of Västergötland similarly has summits, interpreted as the SCP. The area classified as fissure valley landscape in Blekinge is left white in the explaining map with peneplains, but has question marks. This is probably caused by the existence of small occurrences of Cretaceous rocks here. Rudberg (1970) thus considered the interpretation of the extent of the Mesozoic peneplain as unclear.

The undulating hilly land in NE Skåne and most of Halland belongs to areas interpreted as exhumed (re-exposed) pre-Cretaceous relief, while the undulating hilly terrain west and east of southern Lake Vättern occupies areas, where the summits are interpreted as the post-Silurian peneplain. The undulating hilly land along the Göta älv (river NE of Gothenburg) is surrounded by areas defined as the SCP.

The zone with monadnock plains is a higher part of the area interpreted as a Mesozoic peneplain.

\section{Relief descriptions, denudation surfaces of a shield and the peneplain concept}

Rudberg gave first a reliable relief description of bedrock forms in Sweden. He then presented a genetic map of peneplains according to their definition by that time, surfaces of low relief formed by fluvial erosion and graded to a base level (Davis 1899). In this paper, we instead systematically investigate the forms of the basement in relation to cover rocks and note that deep weathering was an important factor in formation of relief in addition to fluvial erosion and slope processes. We have thus been able to define the peneplain concept in a new way (Green et al. 2013; Table 1).

It had been noted that the Precambrian surface of Sweden was early denuded to a surface of low relief (Högbom 1910; Winterhalter et al. 1981; Lidmar-Bergström 1996). First the Svecokarelian rocks were formed (latest ductile deformation 1.8-1.4 Ga) and denuded to a surface of low relief on which the Jotnian sediments were deposited at 1.69-1.25 Ga (LidmarBergström 1996; ages from Stephens et al. 1994). Jotnian rocks of the Almesåkra formation are close to the summit area of the SSD (highest point $377 \mathrm{~m}$ a.s.l.) and are more than $1000 \mathrm{~m}$ thick (Rodhe 1987). Later the Sveconorwegian deformation affected southwestern Sweden (latest ductile deformation 1.0-0.9 Ma acc. to Stephens et al. 1994). During this deformation the Jotnian rocks of the Almesalkra formation were slightly folded and downfaulted (Rodhe1987). The bedrock was again denuded to a surface of low relief on which the Lower Palaeozoic sediments were deposited (Lidmar-Bergström 1996). This is the sub-Cambrian peneplain, which is the primary peneplain of the Swedish Precambrian surface from which all younger relief has developed after its re-exposure (Lidmar-Bergström 1996).

The bedrock surfaces below the cover rocks are named peneplains by Swedish geologists (SCP: Högbom 1910; sub-Mesozic peneplain: Flodén 1992 and Lindström personal communication). In the early definition, the importance of weathering in basement rocks for the final formation of the peneplain, (flat, hilly, plains with residual hills) was not acknowledged, as no information was at hand yet. A peneplain was often considered to be a surface of extreme flatness. Today a flat bedrock surface is labeled a pediplain and is thought to have evolved by surface wash (Büdel 1970), a hilly bedrock surface can be an exposed irregular weathering front (Thomas 1974) but was once a peneplain cutting across a thick saprolite (Fig. 3), and plains with residual hills seem to be epigene peneplains (Lidmar-Bergström 1999) (Table 1). As denudation surfaces, which have marine covers, once have been transgressed by the sea, they can all be regarded as peneplains as they have had a base level and even if they are not flat.

Summary: A peneplain is a surface of low relief (mainly less than $150 \mathrm{~m}$ ) and denotes an area completely different from a mountain area. Such a surface is a geometrical plane identified across a large area but it can also be extended as a summit surface, particularly if it is extremely flat. A peneplain is important for tectonic studies because its current orientation can be used to show how it has been tilted and/or uplifted. The existence of a peneplain (denudation surfaces graded to a base level) is a witness of that uplift forces no longer existed during the final

Table 1. Classification of peneplains in glaciated basement terrain with figures from Rudberg $(1960,1970)$ and Lidmar-Bergström (1995).

\begin{tabular}{lll}
\hline Plain & Pediplain & Relative relief $<20 \mathrm{~m}$ \\
Plains with residual hills & & Residual hills 20-200 m \\
Hilly relief (irregular weathering & Etchsurface & Relative relief $20-200 \mathrm{~m}$
\end{tabular}



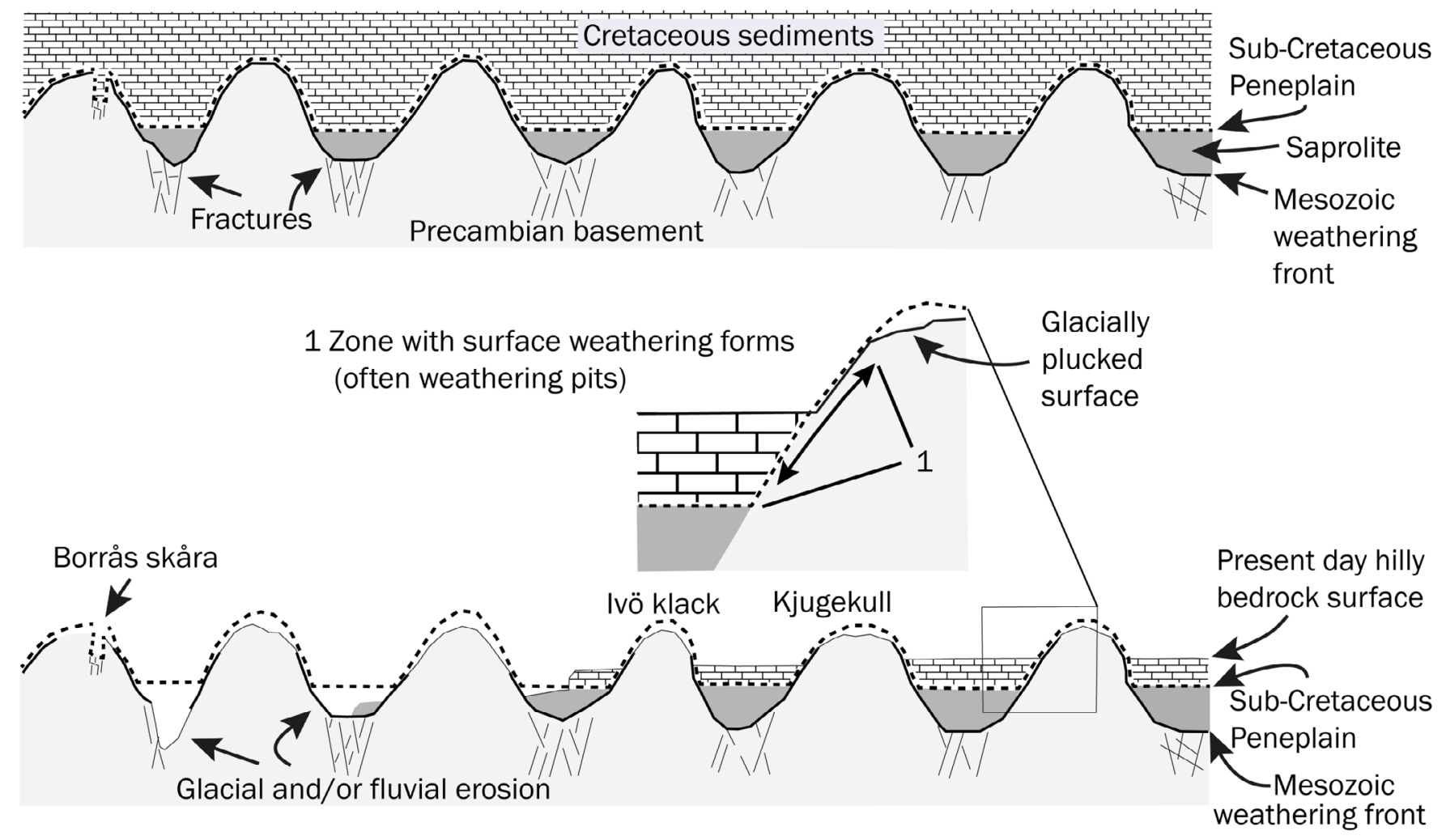

Figure 3. The sub-Creatceous hilly peneplain was formed across a basement with fractures, where deep, clayey, kaolinitc saprolites had formed. The deep weathering caused an undulating weathering front, which partly was exposed before covering by the Upper Cretaceous sediments. The surface of the protruding Precambrian basement hills (e.g. Kjugekull, Ivö klack) got typical surface weathering forms (weathering pits, weathering crusts) during this exposure. Sometimes these surface weathering forms occur on basement boulders from the former Cretaceous bottom conglomerate. After Neogene re-exposure most of the saprolite was eroded and some valleys were further incised by fluvial erosion. Glacial erosion took away most of the remaining kaolinitic saprolites and overdeepended some valleys, often with formation of lakes (e.g. Ivö lake). The occurrence of weathering pits to-day show the comparatively recent evacuation of the once protecting Cretaceous cover.

formation of the peneplain. The peneplain is therefore an important tectonic marker.

\section{The South Swedish Dome}

The SSD is an asymmetric dome making up the South Swedish Uplands formed in Precambrian rocks. The SSD is identified in relation to the SCP, which rises as a prominent landscape feature southwards from Lake Vänern and from below the CambroSilurian remnants in Västergötland as well as from below Cambro-Silurian remnants in Östergötland (Lidmar-Bergström 1988; Fig. 1). The SCP also rises as a landscape feature northwestwards from below the Cambrian cover in southeastern Småland. The sub-Cambrian flat unconformity is identified below sediments in the Baltic along seismic profiles and in borings through the Palaeozoic sediments on Öland, Gotland and offshore and also below Cambrian covers offshore outside the west coast (Ahlberg 1986; Kornfält \& Larsson 1987; Norling 1994). The crest of the SSD is at $377 \mathrm{~m}$ a.s.l. south of Lake Vättern. Lake Vättern has developed along a halfgraben filled with Vendian sediments (Vidal 1982) and dissects the dome crest into two halves. The SCP ends with a distinct scarp to the south and west.

The Precambrian basement disappears to the south and west below Mesozoic sedimentary rocks both onshore and close to the coast offshore. Sub-Mesozoic (sub-latest Triassic, sub-Jurassic, sub-Cretaceous) areas on land, as defined by the aid of outliers, have a hilly relief in basement rocks caused by kaolinitc deep weathering and form an etchsurface (Lidmar-Bergström 1982, 1988, 1994, 1995, 1996). This sub-Mesozoic denudation surface is inclined and cut off at about $125 \mathrm{~m}$ a.s.l. (Fig. 4) by an almost horizontal surface, the South Småland Peneplain (SSP) (LidmarBergström 1982, 1988, 1994, 1996). It includes also a $100 \mathrm{~m}$ surface. Two higher steps were identified, the $200 \mathrm{~m}$ peneplain and the small 300 m peneplain. A 3-D model (Fig. 5) gives an objective picture of the dome and can be compared with the map in Figure 4A.

\section{The role of Cretaceous flints in the reconstruction and interpretation}

In an initial study, flint erratics were mapped in an area between the major Cretaceous deposits of the Kristianstad area (northeast Skåne) and the Båstad area (southernmost Halland) (Lidmar-Bergström 1982). The flints originally emanate from Upper Cretaceous deposits (often black flints). On the west coast there are also Danian flints (often light). Some of the flint erratics on the west coast were interpreted to be of a local character and to show the long persistence of a Late Cretaceous cover lying directly on basement. The flint erratics occur also above the post-glacial Marine Limit (ML) but only below $125 \mathrm{~m}$ a.s.l. on the southern part of the west coast (LidmarBergström 1982). The level for the occurrence of the highest situated flints coincides with a drastic change in gradient of the rivers in Halland, from very low to high, and was named the Upper Cretaceous Limit (UCL) (Lidmar-Bergström 

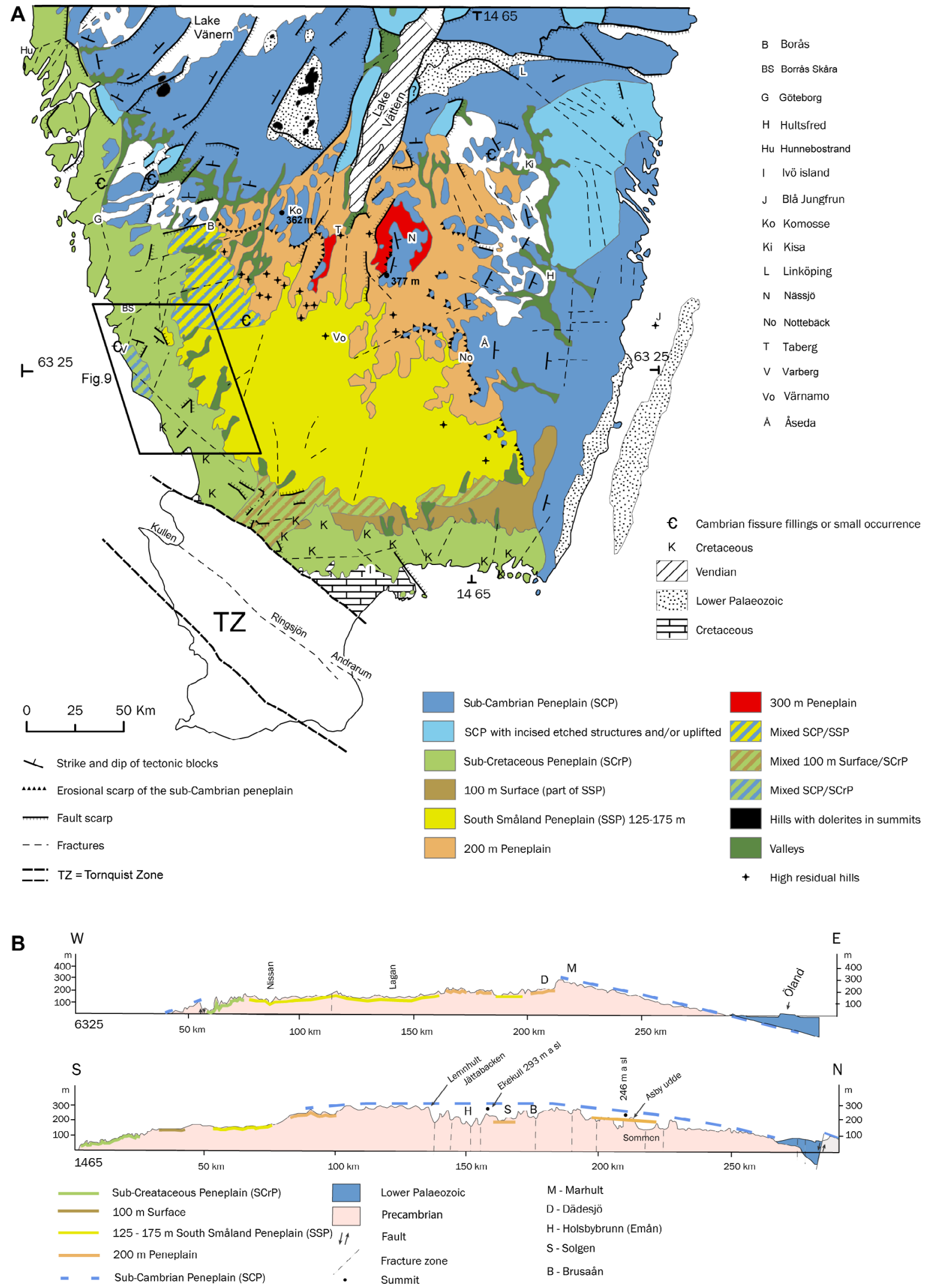

Figure 4. The South Swedish Dome (SSD). A. Map of the SSD with its three main denudation surfaces: (1) the re-exposed Sub-Cambrian flat peneplain (SCP), (2) the reexposed hilly Sub-Cretaceous Peneplain (SCrP, etch-surface), (3) the epigene horizontal plains with residual hills including three horizontal steps (a) the $300 \mathrm{~m}$ Peneplain (minor), intermixed with high parts of the sub-Cambrian peneplain, (b) the $200 \mathrm{~m}$ Peneplain with many and high residual hills (c) the main South Småland Peneplain (SSP) at 125-175 $\mathrm{m}$ a.s.l. with a lower facet, the $100 \mathrm{~m}$ Surface. Mixed peneplains occur in three main areas (1) along the middle and northern part of the west coast there is in places a mixing between sub-Cambrian facets and the major Sub-Cretaceous hilly Peneplain, (2) at the northwestern corner of the SSP there is a mixing with subCambrian facets, (3) the $100 \mathrm{~m}$ Surface in the south (part of the SSP) is partly mixed with the Sub-Cretaceous Peneplain. The location of Fig. 9A is shown. B. East-West profile at 6325 with the eastward facing scarp of the Sub-Cambrian Peneplain . North-south profile at 1465 showing the warped Sub-Cambrian Peneplain with incised valleys and with the $200 \mathrm{~m}$ Peneplain marked as well as the major SSP and the $100 \mathrm{~m}$ Surface. 


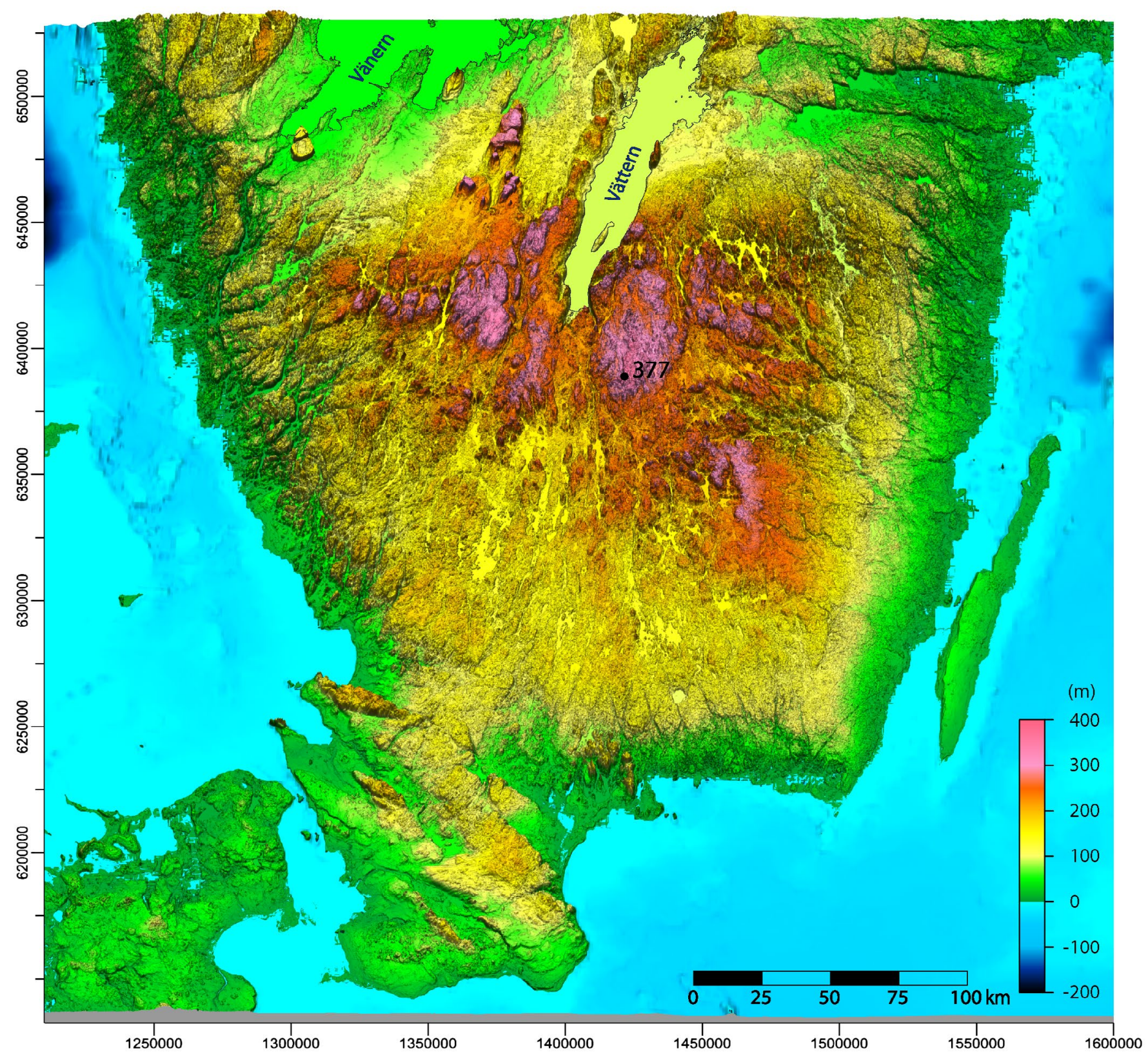

Figure 5. Digital 3D model of the relief of the South Swedish Dome. Elevation data source: Jarvis et al. (2008). Slopes are grey-coloured. Glacial erosion has formed several shallow lakes on the SSP and the $200 \mathrm{~m}$ Peneplain and deep lakes along narrow and weathered fracture zones incised in the uplifted Sub-Cambrinan Peneplain (SCP), while the intact parts of the SCP is avoid of lakes. The eastern high with its highest elevation at $377 \mathrm{~m}$ a.s.l., is close to the SCP, which can be followed as a tilted flat (sometimes summit) surface toward the north, east and southeast, where it is covered by Cambrian sediments (Figs. 1 and 4A). The SCP also makes up the flat surfaces to the south of Lake Vänern, where several cover remnants are making up mesas and buttes. Also here the SCP rises up on the highest summits to the south (cf. Fig. 4A). The SCP is obliterated by younger denudation surfaces in the south and west. Faults in relation to the SCP are seen to the south of Lake Vänern and east of northern Lake Vättern. Major valleys have formed along weathered fractures in the northeast part of the dome. The SSD is identified in relation to the SCP (Fig. 4). For location see Fig. 1.

1982). The UCL slightly rises northwards and is about $135 \mathrm{~m}$ a.s.l. in northern Halland. A horizontal plain with residual hills was identified above the UCL and named the SSP. This means that there must have been a long-lasting Cretaceous cover protecting the irregular weathering front with its deep kaolinitc saprolite (cf. Fig. 3) up to the level of the SSP, when the SSP developed (Lidmar-Bergström 1982). The conclusion was that the SSP represents a younger and deeper cut in the Precambrian basement than the inclined hilly denudation surfaces disappearing below the Cretaceous deposits (Fig. 6a; cf. Rudberg 1982).

\section{The role of new digital elevation data}

In the 1980s, digital elevation data were available for the first time and the SSD was mapped by aid of closely spaced profiles based on digital data (Lidmar-Bergström 1988). By the close profiling, it was possible to trace the inclined SCP up on the highest summits of the SSD. Its coherence in the southeast was confirmed and the question marks by Rudberg (1970) could be erased. The new mapping also revealed the erosional scarp, terminating the uplifted SCP toward the south and west (Fig. 4A). In the far southeast there is no scarp, just a change in slope, but northwards 


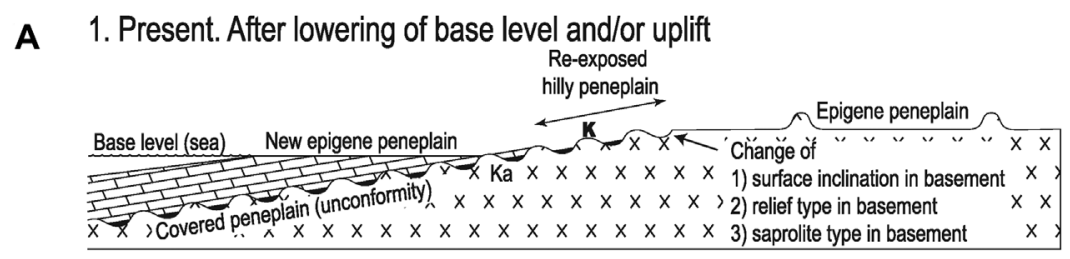

2. Earlier stage. After uplift, tilting and erosion

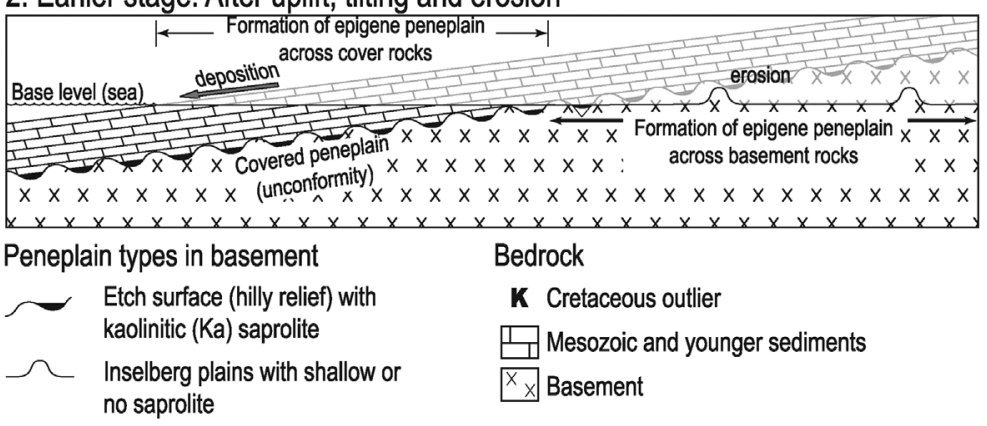

B

Principalsketch across the SSD

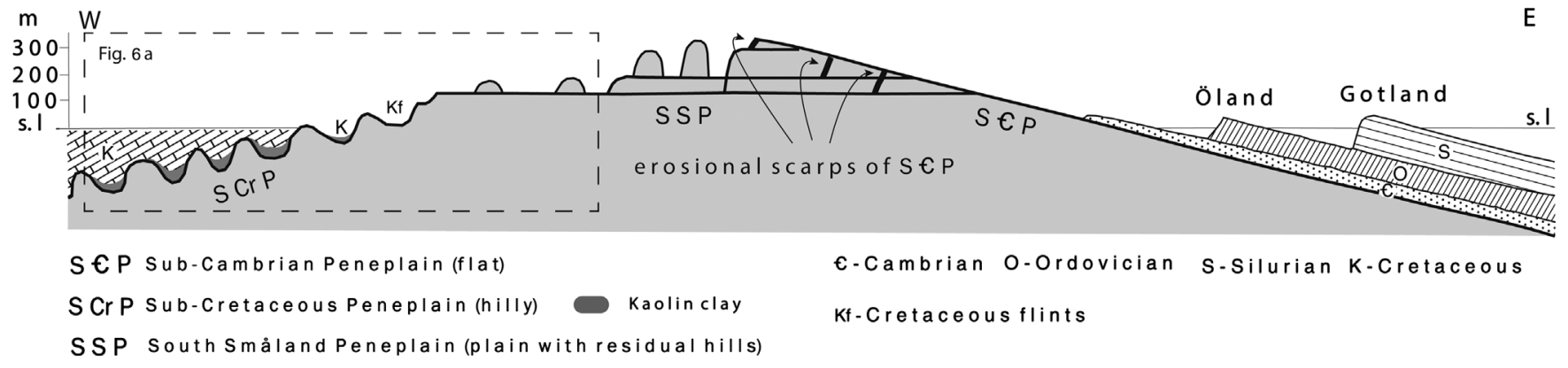

Figure 6. A. Crosscutting relationships between peneplains at the southwestern part of the South Swedish Dome (SSD) (1) and their development (2). Redrawn from Green et al. (2013). For location see Fig. 6B. B. East-west summary profile of the peneplains of the SSD: the Sub-Cambrian flat and inclined Peneplain (SCP) with its westand south-facing scarps, the Sub-Cretaceous hilly and inclined Peneplain (SCrP), and the cross cutting horizontal South Småland Peneplain (SSP) including the $100 \mathrm{~m}$ Surface. Two higher horizontal peneplain steps occur at 200 and $300 \mathrm{~m}$. The Nässjö plateau is a mixture of the $300 \mathrm{~m}$ surface and the Sub-Cambrian Peneplain, which can be traced in the highest summits. The islands of Öland and Gotland are cuestas of the Ordovician and Silurian limestone and seem to have been originally formed by erosion of the Eridano river.

the margin of the SCP forms a scarp, which gets higher and higher. It is up to $75 \mathrm{~m}$ high south of Nottebäck and up to over $100 \mathrm{~m}$ high SW of Jönköping (the scarp from Komosse down to the SSP) (Fig. 4A). It was also found that the highest summits of Småland were close to the highest parts of the inclined SCP and that the high horizontal peneplain at $300 \mathrm{~m}$ a.s.l. only is of minor importance.

The old mapping by Rudberg (1970) better shows the exact location of well-preserved parts of the SCP, while the mapping by Lidmar-Bergström (1988) better shows the continuation of the SCP, even where it is dissected by joint-aligned valleys. The latter mapping is therefore more useful for tectonic conclusions.

\section{Three types of denudation surfaces of the SSD - a description}

Three types of denudation surfaces can be identified across the SSD (Fig. 4A and Fig. 6B; Lidmar-Bergström1988):

The sub-Cambrian inclined peneplain (SCP) has an unusually flat relief (a pediplain) and only in exceptional cases has residual hills. A prominent residual hill, protruding through the Cambrian covers, rises yet on its eastern flank as the island of
Jungfrun (Lidmar-Bergström 1994, 1995, 1996, 1997; Fig. 1B). The Precambrian basement of the SCP is kaolinized up to five meters at the contact with cover rocks (see references in Elvhage \& Lidmar-Bergström 1987), but this saprolite is gone outside the covers. The flat SCP can be followed as a coherent surface and then in summit plateaux up to over $300 \mathrm{~m}$ a.s.l. both southwards from the Cambrian covers in Västergötland and Östergötland and westwards from the Cambrian covers at and outside the Småland east coast. In the southeast the SCP is well preserved up to $300 \mathrm{~m}$ in the vicinity of Åseda. In the northeast, it is dissected by joint-aligned valleys with many remnants of gravelly saprolites (Lidmar-Bergström et al. 1997, Olvmo et al. 2005). The SCP is bordered by an erosional scarp facing southwards and westwards. The crest of the scarp is situated between 130 and over $300 \mathrm{~m}$ a.s.l., rising northwards (Lidmar-Bergström 1988). The escarpment is maximally $100 \mathrm{~m}$ high.

A sub-Cretaceous inclined peneplain (SCrP), an etchsurface with hilly relief, extends from Blekinge, a landscape with jointaligned valleys (sprickdalsterräng; Rudberg 1960, 1970, LidmarBergström 1995), over northeast Skåne with undulating hilly relief (bergkullterräng; Rudberg 1960, 1970, Lidmar-Bergström 1995), and continues along the Swedish west coast with 
undulating hilly relief in the south and a landscape with jointaligned valleys dominating further north. The kaolinitic deep weathering followed fractures downwards and have caused an irregular weathering front (Figs. 3 and 7), which after stripping of the saprolite has caused an irregular relief (Lidmar-Bergström 1989). The abandoned quarry at Blaksudden, Ivö island (Fig. 7), northeast Skåne (Fig. 4A), is the most important site for identification of the sub-Cretaceous irregular surface and the process that formed it. The Mesozoic deep weathering event started in the Rhaetian (Lidmar-Bergström 1982, Ahlberg et al. 2002, 2003). The sub-Cretaceous hilly surface is identified with the aid of remnant Cretaceous covers, in some cases verified by minor Cretaceous subaerial weathering forms as at Kjugekull (SW of Ivö island) and other places (Magnusson \& Lidmar-Bergström 1983, Lidmar-Bergström \& Magnusson 1984), erratic Cretaceous flints, and remnants of a deep kaolinitic clayey saprolite (max. $60 \mathrm{~m}$ deep) (Lidmar-Bergström 1982, 1985, 1988, 1989) (Fig. 3). The subaerial weathering forms of the sub-Cretaceous surface occur either in the Precambrian bedrock in situ or in loose Precambrian boulders originating from the Cretaceous bottom conglomerate (Fig. 8). Borrås skåra (Figs. 3 and $4 \mathrm{~A}$ ) shows typical sub-Cretaceous weathering forms in the Precambrian bedrock, as a weathering pit and an old weathering crust (Lidmar-Bergström \& Åkesson 1987.

There are three horizontal steps in west Småland/south Västergötland, characterized by plains with residual hills (LidmarBergström 1988; Fig. 4A):

(1) The main South Småland Peneplain (SSP) rises slowly from its southwestern border northeastwards and is a continuous surface from about 125 to $175 \mathrm{~m}$ a.s.l. It carries a few residual hills. A slightly lower facet is defined along its southern border between $100 \mathrm{~m}$ and $125 \mathrm{~m}$ a.s.l. (the $100 \mathrm{~m}$ Surface). The $100 \mathrm{~m}$ Surface is somewhat problematic and is probably a mixed surface (see below).
(2) A higher horizontal step extends above $200 \mathrm{~m}$ a.s.l, the $200 \mathrm{~m}$ Peneplain. The $200 \mathrm{~m}$ Peneplain carries many residual hills. They are particularly high along its southwestern rim. They reach here between 281 and $341 \mathrm{~m}$.a.s.l. The heights of individual hills are between 60 and $150 \mathrm{~m}$. This latter area coincides with the area, which Rudberg (1960) named a monadnock plain (Fig. 2A).

(3) A highest peneplain step may be recognized above $300 \mathrm{~m}$ a.s.l. (the $300 \mathrm{~m}$ Peneplain) regarded here as mainly mixed with the highest parts of the re-exposed SCP (see below).

\section{Mixed peneplains}

In the northwestern part of the SSP, there are areas that are somewhat higher than the main SSP. Some areas here are at the level of the $200 \mathrm{~m}$ peneplain. However, they are at certain places extremely flat and resemble typical parts of the SCP. There is also a Cambrian fissure filling at Smålands Burseryd (personal communication Anders Martinsson in the 80ies; symbol for Cambrian fissure filling Fig. 4A). Thus, there is an area with relief mixed between the SSP and re-exposed facets of the SCP (Fig. 4A). Such peneplains are here named mixed peneplains (cf. "mixed relief" in Lidmar-Bergström 1996).

The sub-Cambrian flat peneplain and the hilly sub-Cretaceous peneplain (SCrP) are intermixed along the coast in central and northern Halland (Figs. 4A and 9) and maybe also in southern Bohuslän. The SCP can be traced in two ways: (1) Cambrian fissure fillings occur at several places on the northwestern part of the SSD and along parts of the west coast (Mattsson 1962, Samuelsson 1975, 1978, 1982). There are, for example, Cambrian fissure fillings at Getterön outside Varberg (Fig. 9A) and probably also further south along the coast (Påsse 1990). (2) Flat areas in the Varberg area have been shown to lie on the end of a line

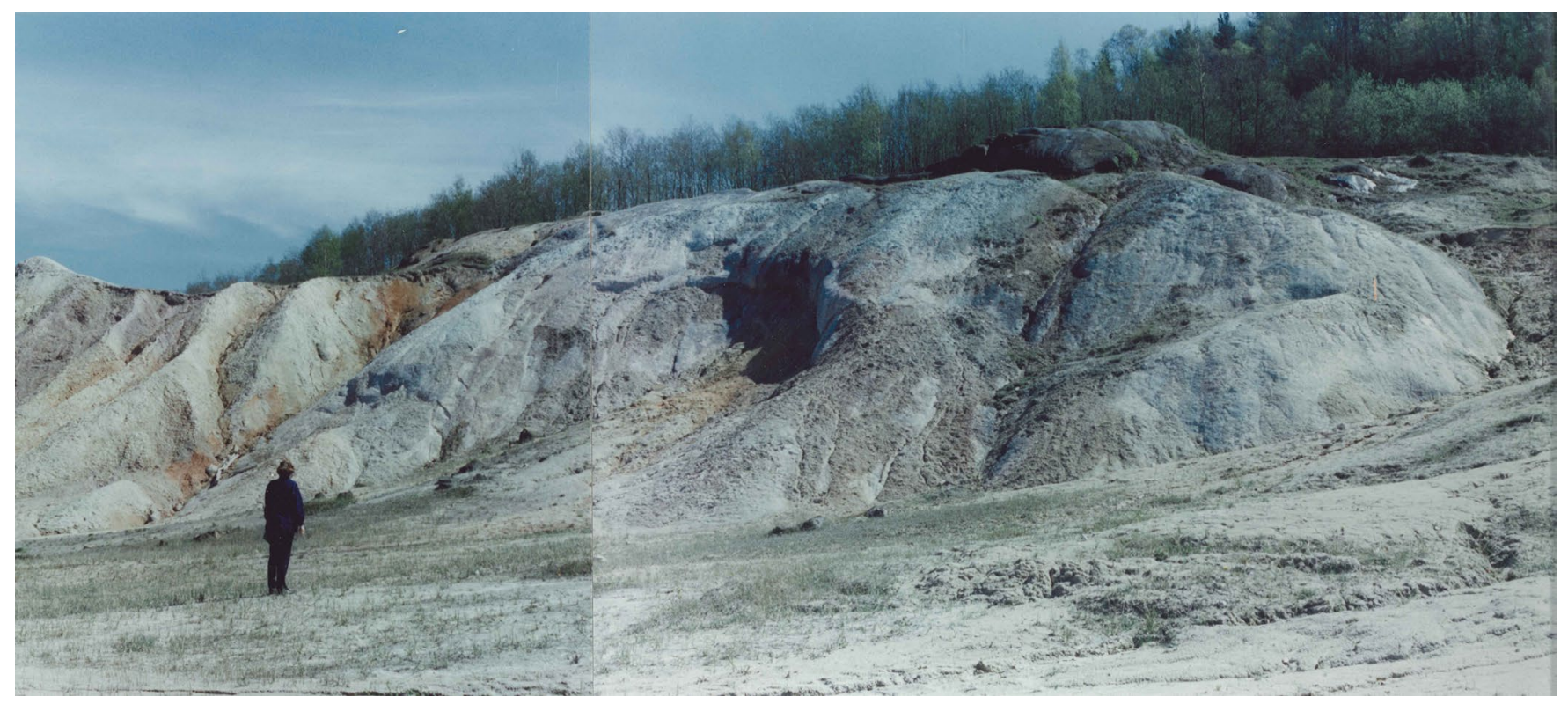

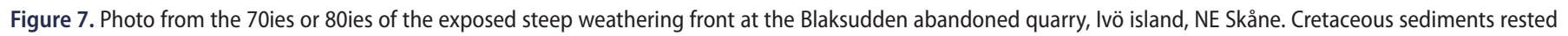
once on the rock surfaces at the top, while the major part of the photo shows the steep weathering front (exposed by kaolin quarrying) and to the left the remaining clayey, kaolinitic saprolite. Photographer: Jan Bergström. 

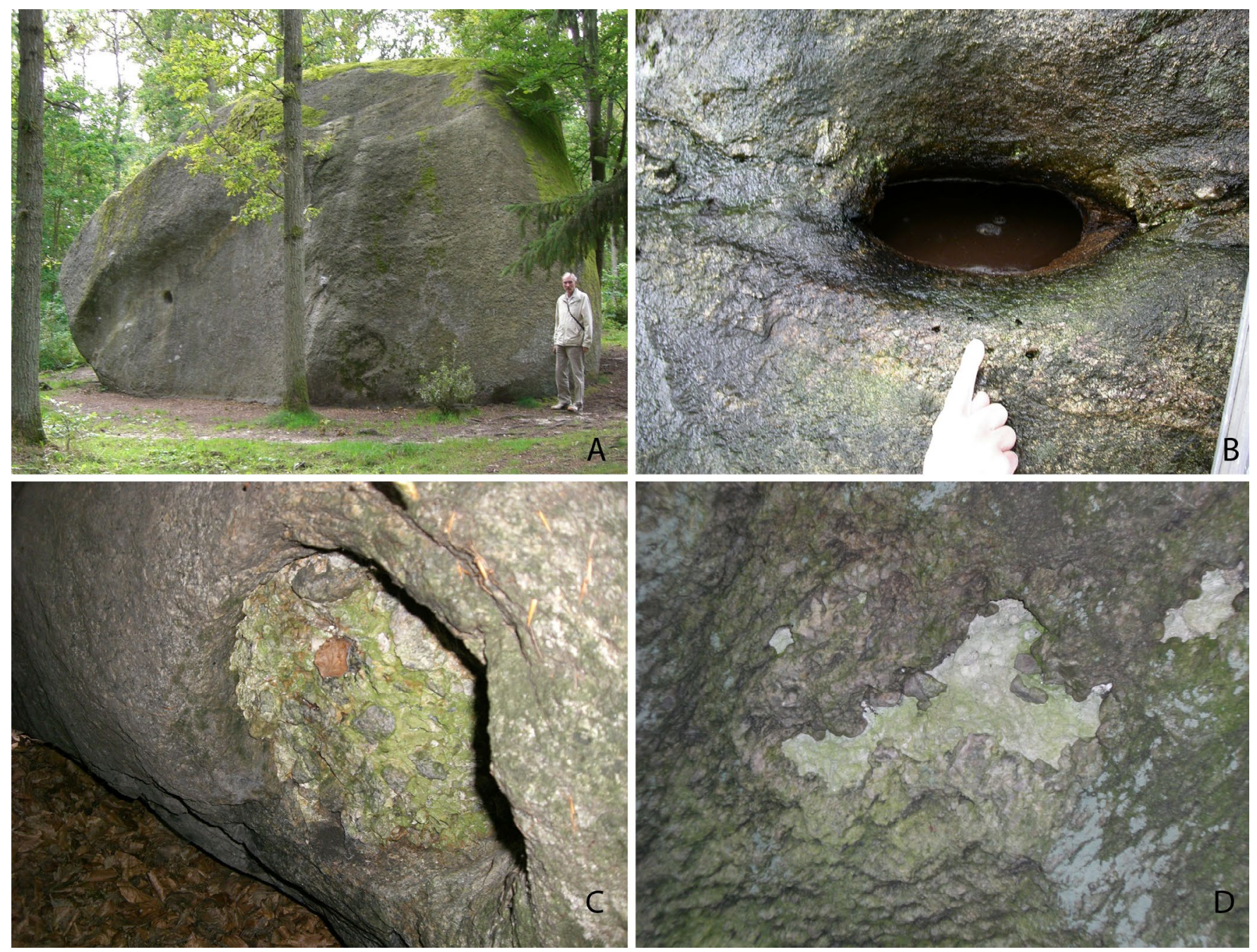

Figure 8. Weathering pits and weathering crusts were formed on bedrock hills, which protruded the deep, clayey, and kaolinitic saprolites, and before the Cretaceous covering (Fig. 3). The present occurrence of such weathering pits and crusts suggests a late removal of the Cretaceous cover. A. A Precambrian boulder at Kjugekull, Skåne, with weathering pit and rough weathering crust (in the foreground to the wright). The boulder is detached from the Cretaceous bottom conglomerat, which once existed. B. Weathering pit in bedrock wall at Penningberget, Karlshamn, Blekinge, where Cretaceous remnants still occur. C. Weathering pit in detached boulder on Kjugekull with preserved Cretaceous infilling. D. Weathering crust in detached boulder at Kjugekull with Creatrceous remnants.

through higher and higher summits of a row of hills to the south. The line is interpreted to show the position of a NW-tilted SCP, as it ends in areas with low relief and Cambrian fissure fillings (Åkesson 1990; Fig. 9 B; Table 2), an interpretation supported by the flow direction (northwestwards) of the Suseån River. As the coastal hilly relief mainly is part of the sub-Cretaceous hilly peneplain, a mixture of sub-Cambrian and SCrPs occurs here. The SCP is close to many summits, while the relief at large is hilly and has experienced weathering along fracture zones before the Cretaceous covering, maybe here in the Santonian (cf. Bergström et al. 1973).

The highest parts of the inclined SCP almost interfere with the horizontal $300 \mathrm{~m}$ peneplain and the two peneplains form together the Nässjö plateau and the plateau SW of Taberg (Figs. $4 \mathrm{~A}$ and $6 \mathrm{~b}$ ).

In north central Skåne, several Cretaceous outliers are encountered in an area with flat relief, which forced Rudberg (1970) to regard the plain of southern Småland to be a Mesozoic plain. Instead, the $100 \mathrm{~m}$ surface here is now regarded as mixed with the SCrP (Fig. 4A).

\section{Clayey and gravelly saprolites of the SSD - summary}

Saprolites of different palaeosurfaces were investigated by Lidmar-Bergström et al. (1997). Saprolites encountered in direct relation to Cambrian cover rocks are thin $(<5 \mathrm{~m})$ and clayey with kaolinite as the main component among the clay minerals. Saprolites encountered below Cretaceous and Jurassic (maybe also uppermost Triassic; see inquest by Lidmar-Bergström 1982; fig. 29) strata are thick (up to $60 \mathrm{~m}$ ), clayey and dominated by kaolinite in the fine fraction, while saprolites encountered within the SSP and in the valleys incised in the SCP are gravelly and of moderate thickness (up to at least $15 \mathrm{~m}$; Olvmo et al. 2005). The gravelly weathering (saprolite) is particularly abundant in the eastern part of the SSP and the higher $200 \mathrm{~m}$ peneplain. It is also common in joint-aligned valleys incised in the SCP. The fine fraction of the latter saprolites normally constitutes less than $5 \%$ and is characterized by a mixed clay mineral composition including different clay minerals as vermiculite and illite. SEManalyses of micro textures on quartz grains confirm the difference between the clayey and the gravelly saprolites. These gravelly saprolites also occur on well-preserved parts of the re-exposed 
A Peneplains

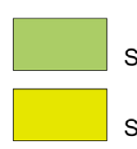

Sub-Cretaceous Peneplain (SCrP), hilly

South Småland Peneplain (SSP) horizontal

Mixed peneplains

Tectonics

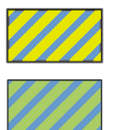

Sub-Cambrian Peneplain (SCP)/SSP $\quad-\quad$ Strike and dip of tectonic blocks related to SCP

SCP (in summits)/SCrP
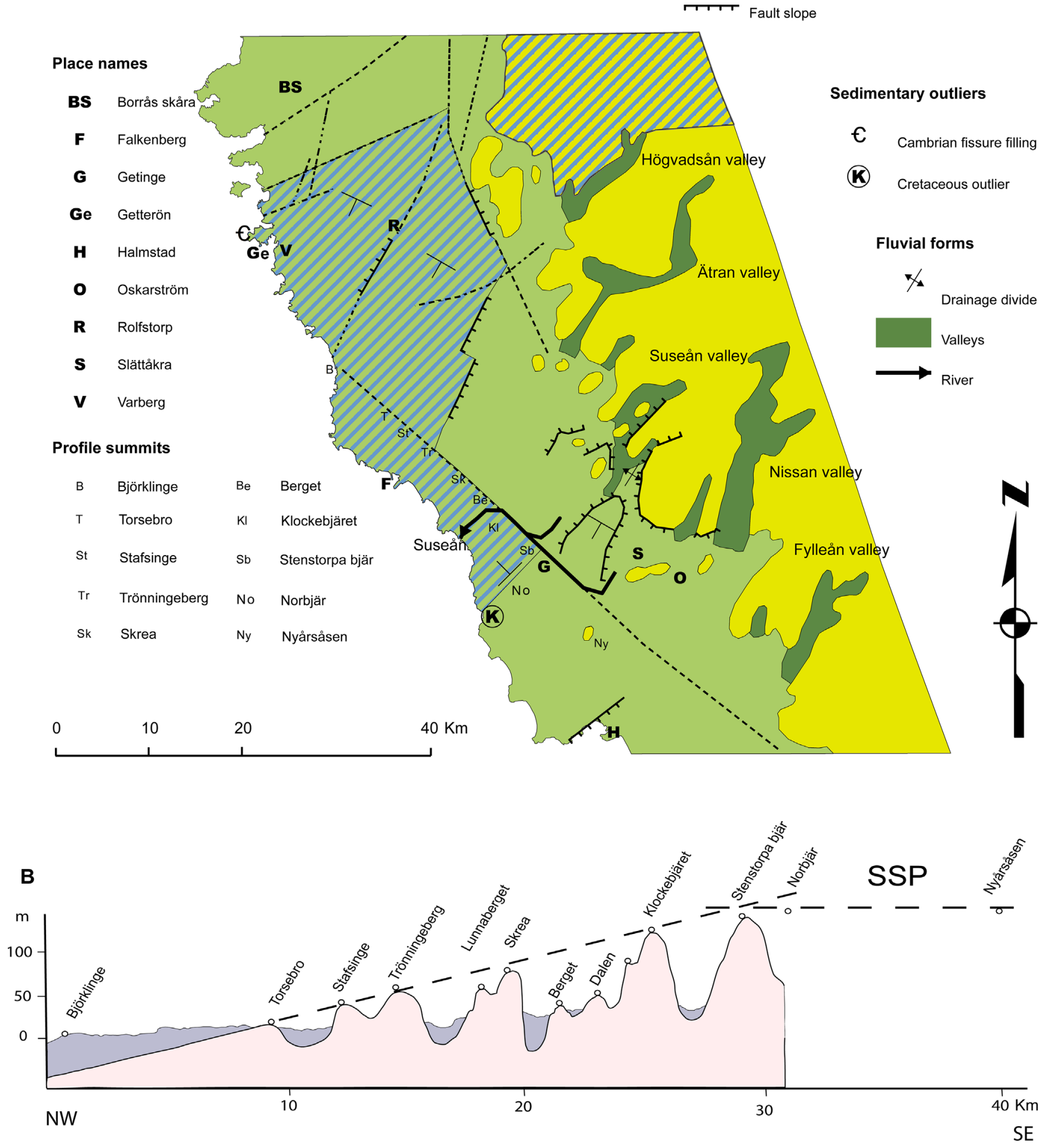

Figure 9. West coast of Halland. A. Map with mixed relief and tectonic blocks (for location see Fig. 4A). Detailed information from base maps for the map in LidmarBergström (1988), from Åkesson (1990) and from Lidmar-Bergström \& Åkesson (1987). Note the valleys incised in the SSP to the east. B. Profile southwest of and along NW-SE fracture zone showing a NW-tilted tectonic block with the Sub-Cambrian Peneplain in the summits. The hilly relief is formed after exposure from the Palaeozoic rocks and before the cover of the Cretaceous rocks was deposited in the Santonian (Bergström et al. 1973). 
Table 2. Bedrock hills with heights along profile of Fig. 9B from Björklinge to Getinge showing summits reaching (not those in brackets) the tilted sub-Cambrian peneplain (SCP). At about $135 \mathrm{~m}$ the summits are cut by the SSP. The irregular relief belongs to the sub-Cretaceous peneplain ( $\mathrm{SCrP}$ ). Thus the profile shows a mixture of peneplains.

\begin{tabular}{lc}
\hline Torebro & $17 \mathrm{~m}$ \\
Stafsinge & $40 \mathrm{~m}$ \\
Tröinge berg & $50 \mathrm{~m}$ \\
(Lunnaberget & $55 \mathrm{~m})$ \\
Skrea & $75 \mathrm{~m}$ \\
Berget & $35 \mathrm{~m}$ \\
(Dala & $50 \mathrm{~m})$ \\
Klockebjäret & $120 \mathrm{~m}$ \\
Stenstorpa bjär & $130 \mathrm{~m}$ \\
(Norbjäret & $140 \mathrm{~m}$ ) \\
(Nyårsåsen & $141 \mathrm{~m}$ ) \\
\hline
\end{tabular}

SCP, but in these cases they are always less than $3 \mathrm{~m}$ thick (Olvmo et al. 2005).

\section{Stratigraphic Landscape Analysis and Phanerozoic tectonics}

Stratigraphic Landscape Analysis (SLA) (Lidmar-Bergström et al. 2013) is the method in which peneplains/denudation surfaces are defined and mapped, and then analyzed in relation to each other to draw conclusions on Phanerozoic tectonics. It was developed through the research of the SSD and thereafter applied to West Greenland (Bonow et al. 2006a, and other places (Bonow et al. 2007, 2009, Japsen et al. 2009, Lidmar-Bergström et al. 2013, Bonow et al. 2014).

\section{Re-exposed peneplains}

Re-exposed peneplains have been known for at least a century (e.g. Högbom 1910, Twidale 1976) and have been named "exhumed" peneplains. However, as the term "exhume" now is used for erosion of rocks by many geophysicists, the term "re-exposed" is preferred. These peneplains have earlier just been dated by the cover rocks, while their importance to reveal tectonics has been overlooked. Here, we show how a peneplain can be used as reference for conclusions on faulting, doming and uplift.

The SCP of Sweden has long been a surface of reference for identification of faults in central Sweden (De Geer 1910, Rudberg 1970). Vertical faults, mapped in relation to both sedimentary covers of different age and re-exposed peneplains, were presented in a map of all of Sweden by Lidmar-Bergström $(1994,1996)$ and partly reproduced later (Lidmar-Bergström \& Olvmo 2015). Tectonic blocks were identified in relation to the SCP (LidmarBergström 1996, Lidmar-Bergström \& Olvmo 2015). Similarly, tectonic blocks were identified in relation to the SCP at the northwestern flank of the SSD as described in this paper.

The hilly SCrP in Blekinge, northeast Skåne, and Halland, suggests that its type of relief gives witness to a former Mesozoic cover also in other areas with kaolinitic, clayey saprolite remnants. As this hilly relief continues northwards along the west coast, into Norway, and further across large parts of central Sweden up to Lapland, it has been suggested to serve as evidence to the occurrence of former Cretaceous covers, although the kaolinitic, clayey saprolite remnants are fewer and cover remnants are absent (Lidmar-Bergström 1999). Covers and most of the saprolite must have been removed here late due to erosion after uplift (Lidmar-Bergström et al. 2013).

Phanerozoic faulting can also be identified by the aid of layers of covers rocks of different age. The Tornquist Tectonic Zone in southernmost Sweden reveals a long history of vertical movements since the Late Silurian (Norling \& Bergström 1987). Offshore investigations around southernmost Sweden have given additional information (Erlström \& Sivhed 2001). However, the mapping of re-exposed Phanerozoic peneplains makes it possible to draw conclusions on Phanerozoic tectonics even in basement areas devoid of sedimentary covers.

\section{Epigene peneplains}

A second category of peneplains, in contrast to the re-exposed, are the epigene (Twidale 1985), those who have never been covered. The SSP is an example of such a coherent peneplain graded to a distinct base level (Fig. 4A). It cuts off a re-exposed tilted peneplain and it is retreating backwards into the uplifted SCP. Its existence contradicts recent suspicions on the non-existence of peneplains (Phillips 2002). The base level for such epigene, often horizontal, peneplains can be used to measure the amount of uplift since their initiation (Lidmar-Bergström 1991, 1993; Bonow et al., 2006a, 2006b; Japsen et al. 2009; Lidmar-Bergström et al. 2013).

A stepped sequence of epigene peneplains, as on the western side of the SSD, is often seen in highland areas (piedmont benchland according to Ahnert 1998, piedmont treppe according to Penck 1924). We have here shown that these epigene peneplains are young, mainly Neogene. Re-exposed peneplains, on the other hand, are the result of prolonged denudation and therefore do not show any preserved distinct steps.

\section{Phanerozoic uplift events of the SSD based on SLA}

The analysis of the cross-cutting relationships between different re-exposed and epigene peneplains, SLA, is a new tool for deciphering Phanerozoic uplift events (Green et al. 2013; LidmarBergström et al. 2013).

The basement was denuded to a peneplain (extremely flat and of pediplain character; Table 1) before the Cambrian transgression (Elvhage \& Lidmar-Bergström 1987). It was mainly cut across the basement after the Sveconorwegian folding (900 Ma) and before the Vendian sedimentation and got its ultimate form before $542 \mathrm{Ma}$ after erosion of the Vendian covers. A thick pile of Cambro-Silurian sediments were then deposited on top of this SCP, which we know from surrounding sediments (e.g. Winterhalter et al. 1981; Bergström \& Gee 1985; Ahlberg 1986; Artyushkov et al. 2000; Nielsen \& Schovsbo 2011). From the profile (Fig. 1B) it is clear that the Palaeozoic cover was gone and basement exposed in the Mesozoic along parts of the area covered by the western part of the profile. Mesozoic sediments (mainly Jurassic and Cretaceous) rest directly on a kaolinized, hilly basement in central and northeastern Skåne, in Blekinge, and in southern Halland (Lidmar-Bergström 1982, 1989; Wikman \& Bergström 1987; Kornfält \& Bergström 1991). These areas are mapped as sub-Cretaceous and sub-Jurassic etchsurfaces and extend as inclined peneplains along the southern and western flanks of the SSD (Fig. 4). These areas must thus have 
been uplifted and exposed to denudation during the Mesozoic (Lidmar-Bergström 1991, 1993, 1994, 1995, 1996; Japsen et al. 2002) maybe in two events with intervening covering (Japsen et al. 2016). These areas were subsequently tilted down and successively covered by Jurassic and Cretaceous sediments

The border in the south and west between the inclined SCrP and the horizontal SSP is identified by the changing morphology of the bedrock (hilly and flat with residual hills, respectively), the disappearance of Cretaceous remnants at the border, and the change here in type of saprolite remnants (kaolinitic clayey saprolite and gravelly saprolite) (Fig. 6a). Since the paper by Lidmar-Bergström (1982), new observations on the transgression of the Cretaceous sea have been made. The highest situated sedimentary Cretaceous remnants in Skåne are of Campanian and Maastrichtian age (Wikman et al. 1983; Gabrielson \& Holland 1984). At some of the localities the Campanian strata are fine grained, indicating deep water. The remnants of Maastrichtian sediments at $95 \mathrm{~m}$ a.s.l. in northern Skåne show deep-sea affinities of the fossils, which suggest a water depth of at least 100-200 m (Gabrielson \& Holland 1984). At least both the Campanian and Maastrichtian transgressions went higher than the present SSP, which confirms that it is a younger and deeper cut in the Precambrian basement than the sub-Cretaceous etchsurface (Fig. 6a).

According to apatite fission-track thermochronology, there might have been 1-2 km of covering sediments across most of southern Sweden, before erosion of the cover rocks started in the Early Miocene (Japsen et al. 2016). Deep water covered the Denmark area in the Eocene as described by Spjeldnæs (1975). Knox et al. (2010) placed a sedimentary cover across southern Sweden in the Late Paleocene and Early Eocene. Both interpretations support the conclusion of a long-lasting cover across the SSD.

Rasmussen et al. (2010) studied the palaeogeography in the North Sea Basin and concluded that the Early - early Middle Miocene was a time when major deltas prograded from the north and northeast into the North Sea Bain, and the rivers that supplied the sediments had their headwaters in present-day central Sweden. The cause for sedimentary influx was regarded to be uplift to the northeast, which probably coincides with the start of the uplift of the SSD.

It must have been during this Miocene uplift (Japsen et al. 2016) that the SSD started to get its present form. The uplift was centered south of Lake Vättern as the highest remnants of the SCP occur here. Successively, the horizontal steps were shaped. Drainage was to the southwest, and the erosional scarp of the uplifted SCP retreated northwards and eastwards leaving the residual hills. The NW-SE line with high residual hills might represent an older position toward the SW of the scarp of the uplifted and tilted SCP. Old fractures were opened due to the uplift, and water in the fractures facilitated the formation of gravelly saprolites (Lidmar-Bergström et al. 1997; Olvmo et al. 2005). Valleys formed subsequently in the uplifted and tilted SCP by erosion of the saprolites in the fractures. At last the SSP was formed across both basement and the Cretaceous cover to the south and west (Fig. 6a). It is clear from the gravelly saprolites that the present basement surface of Småland was not re-exposed from its covers until the Late Miocene at the earliest, as that is the time for the beginning of gravelly saprolites to form (Migon
\& Lidmar-Bergström 2001). Thus, the uplift starting in the Early Miocene must have first caused erosion of sedimentary covers and re-exposure of the highest parts of the SCP and thereafter formation of the present horizontal steps in the basement. The steps were formed on the expense of a re-exposed hilly etchsurface in the south and west but incised in the sub-Cambrian flat peneplain in the north and east. The age of formation of the horizontal steps in the basement with their gravelly saprolite remnants might thus be from the Late Miocene to the latest uplift at $4 \mathrm{Ma}$ (Japsen et al. 2016).

This latest uplift phase caused re-exposure of the sub-Cretaceous hilly relief below the level of the SSP, which means below 125 (100) $\mathrm{m}$ a.s.l. in the south and slightly higher northwards along the west coast (135 $\mathrm{m}$ a.s.l. in northern Halland). LidmarBergström et al. (2013) correlated the SSP with the lowest of the Palaeic Surfaces in southern Norway.

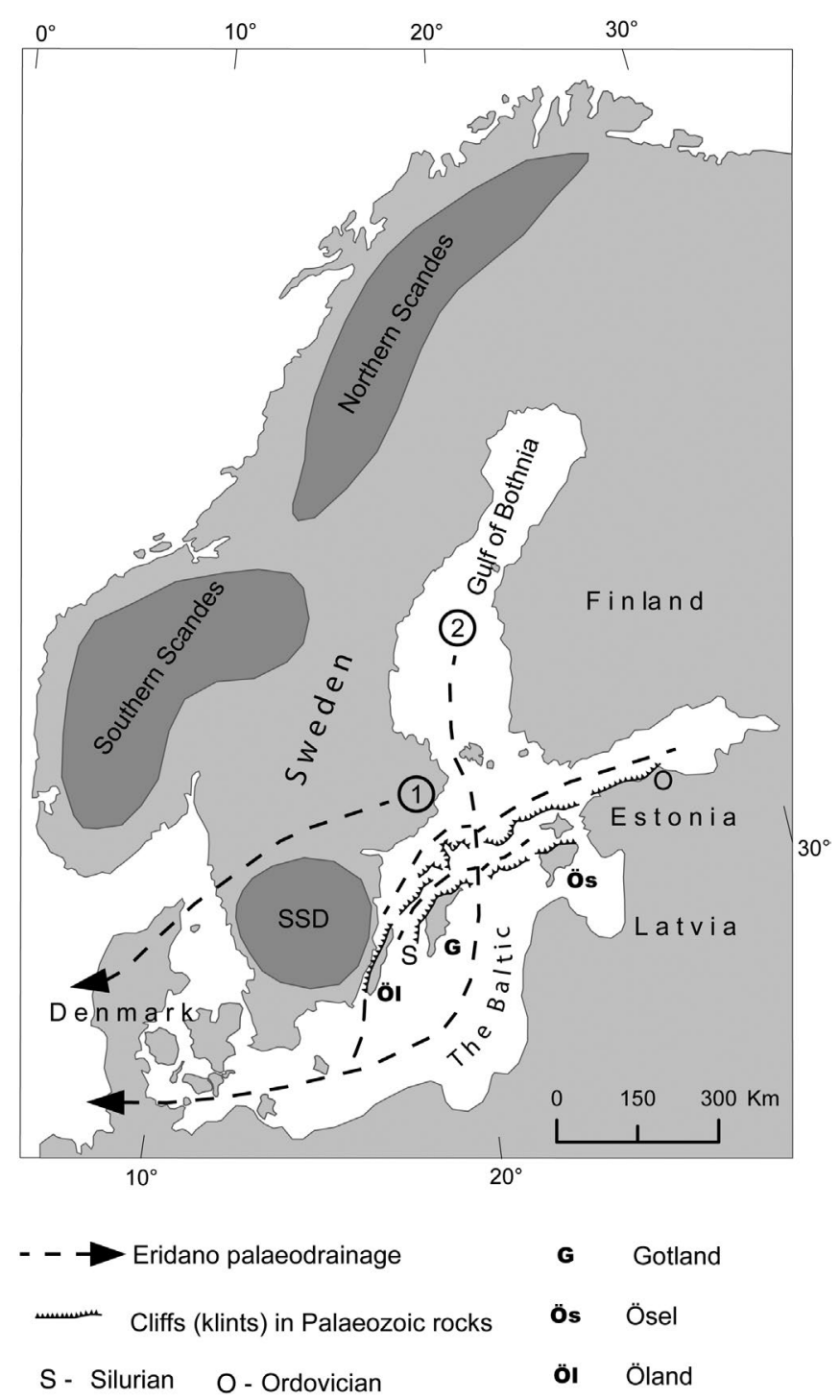

Figure 10. Map of Scandinavia with its three uplift areas Northern Scandes, Southern Scandes, and the South Swedish Dome (SSD) (Lidmar-Bergström et al. 2013) and the development in two steps of the Eridano river draining the Gulf of Bothnia and the Gulf of Finland (Spjeldnæs 1975; Blijsma 1981; Overeem et al. 2001). The location of the klints, the Ordovician (0) and Silurian (S), is from Martinsson $(1958,1979)$. Öl = Öland. G = Gotland. Ös = Ösel. D = Dagö. 
The mixed peneplains at the northwestern end of the SSP, including sub-Cambrian facets and the mixing of the sub-Cambrian and SCrPs along parts of the west coast, show that the SCP was faulted in this area before the formation of both the $\mathrm{SCrP}$ and the SSP.

\section{Evidences of erosion from the offshore sedimentary record related to the formation of the SSD and the Eridano River}

This story of Miocene uplift and exposure of the SSD is supported by information from offshore sediments (Clausen et al. 1999). Sediments from Norway reached the areas west of Denmark in the Oligocene/ Early Miocene, while sediments from Late Miocene and onwards came from the northeast, the SSD area. In the Pliocene, the sediments west of southern Denmark arrived from the east (Spjeldnæs 1975; Blijsma 1981; Rasmussen et al. 2010) and a river, the Eridano River, drained the Baltic Basin (Overeem et al. 2001). This suggests that the uplift of the SSD blocked drainage of the Baltic Basin southwestwards across the SSD in the Pliocene and instead the Eridano River (Fig. 10) started to form with drainage to the south of SSD.

It is possible that a proto-Eridano (1 in Fig.10) first formed north of the SSD (cf. Spjeldnæs 1975). It is probable that during the uplift of the SSD the Eridano-river caused the formation of cliffs (klints) in the Palaeozic rocks of the Baltic. Today there are two major klints, partly submarine (Martinsson 1958, 1979; Tuuling \& Flodén 2016): (a) the Ordovician klint from Öland, across the sea bottom, and along the coast of northern Estonia; (b) the Silurian klint from Gotland, across the sea bottom, and along northern Ösel. A first Eridano river might have formed west of Öland, while the major river (2 in Fig. 10) probably followed the present low areas of the Baltic. As glacial erosion is thought to have changed the bottom topography, it is difficult to make a correct reconstruction. However, it is possible that the low position of the Baltic Sea areas partly is due to subsidence in connection with uplift of the SSD.

\section{Relief, saprolites, peneplains and glacial erosion}

Both landscapes with joint-aligned valleys and hilly terrain are shown to have developed by deep weathering of fractures. It is the type of remnant saprolites that separates those formed during the Mesozoic rom those formed during the Neogene (LidmarBergström et al. 1997).

Where the SCP is well preserved to-day, the protecting cover rocks must have disappeared late. However, thin gravelly saprolites on well-preserved parts of the uplifted and tilted SCP (Olvmo et al. 2005) show that there was time for them to form. Gravelly weathering started to form at the earliest in the Late Miocene (Migon \& Lidmar-Bergström 2001). As the gravelly saprolites are judged to have been formed during the PlioPlieistocene (Lidmar-Bergström et al. 1997), we suggest that these thin saprolites on the well-preserved SCP formed during the late Pliocene into the Pleistocene.

There is a difference between the erratic Cretaceous boulders encountered in the higher areas of southern Halland and northeastern Skåne. In Skåne there are both flints and calcarenite remnants in the tills, while in Halland there are only flints, which often are weathered (Lidmar-Bergström 1982). The interpretation is that in southern Halland the preglacial weathering and erosion after uplift and exposure of the Cretaceous rocks were more intense than in northeastern Skåne, where glacial erosion has mainly encountered Cretaceous deposits still in situ.

The existence of the three types of peneplains (the sub-Cambrian flat peneplain, the sub-Cretaceous hilly peneplain and the epigene peneplains with residual hills in four steps) shows that glacial erosion was not able to destroy the large-scale relief features (Lidmar-Bergström 1997; Olvmo et al. 1999; Johansson et al. 2001). Even in areas with glacial scour, as in parts of Blekinge and Bohuslän (Johansson et al. 2001; Kleman et al. 2008), the irregular relief and the Cretaceous outliers witness that the major landforms belong to an old etch surface, the SCrP.

\section{Conclusions}

The results in this paper are based on observations of the relationships between forms in the basement and its cover. Observations have always been the basic data for geology. Today there are many different new techniques that give new and interesting results, but it is important to note that primary observations always are the base.

The relationships between peneplains with different detailed morphology in basement rocks are important in deciphering Phanerozoic tectonics. The SSD is a key structure in basement terrain for identifying re-exposed peneplains of different age as well as crosscutting horizontal epigene peneplains. The SSD is therefore a reference area for SLA. The different peneplains are used to reveal the tectonic development of the SSD in four stages: (1) formation of the SCP over the whole area and its subsequent covering. (2) Uplift in the southwest in the Mesozoic, erosion of covers and denudation into the basement with formation of an etched hilly peneplain, which after partial exposure of the weathering front was tilted down and covered. (3) Uplift centered to the south of Lake Vattern during the Miocene causing erosion of covers, re-exposure of the SCP in the north and east, formation southwestwards of three horizontal steps, characterized by plains with residual hills, to successively lower base levels. (4) Minor uplift (increasing northwestwards) of the whole dome during the Pliocene, causing re-exposure at low elevations of sub-Cretaceous hilly relief in the west and south as well as of sub-Cambrian flat relief in the east. The setting of the SSD shows that peneplains exist and are useful in deciphering Phanerozoic tectonics even in areas of Precambrian basement rocks outside the coherent Phanerozoic covers.

\section{Acknowledgments}

Karna Lidmar-Bergström thanks her late husband, Jan Bergström, for daily discussions during the time in Lund on the contact of the Precambrian basement surface and the cover rocks (Jurassic and Cretaceous) and for the many joint excursions in Halland, Skåne and Blekinge. Jan's knowledge of the possible provenance of erratic boulders was of utmost value during field trips. During his stay at the Geological Survey in Lund, Jan made many of the map sheets with Cretaceous sedimentary rocks and there was a mutual benefit between Karna and her husband on the relationships between the basement surface and its cover rocks. Grants from the Science Council during the years 1982-2005 were the economic base for the work by Karna after finishing of her thesis in1982 as well as economic salary support from the Deparment of Physical Geography at the 
University of Stockholm (1994-2004) and the Faculty of Natural Sciences at the University of Stockholm (1995-2001). During several years Mats and Karna worked together on saprolites in southern Sweden and Siv Olsson, Department of Quaternary Geology, Lund, made all our X-rays of the sampled saprolites and joined us during several field trips.

\section{Disclosure statement}

No potential conflict of interest was reported by the authors.

\section{References}

Ahlberg, P., 1986: Den svenska kontinentalsockeln berggrund. Sveriges geologiska undersökning. Rapporer och meddelanden 47. 101 pp.

Ahlberg, A., Arndorff, L. \& Guy-Ohlson, D., 2002: Onshore climate change during the late triassic marine inundation of the Central European Basin. Terra Nova 14, 241-248.

Ahlberg, A., Olsson, I. \& Šimkevičius, P., 2003: Triassic-Jurassic weathering and clay mineral dispersal in basement areas and sedimentary basins of southern Sweden. Sedimentary Geology 161, 15-29.

Ahnert, F., 1998: Introduction to Geomorphology, 352. Arnold, London.

Åkesson, G., 1990: Berggrundens former och vittring $i$ mellersta Halland. Unpublished Master Science thesis (C-uppsats). Uppsala universitets naturgeografiska institution. $67 \mathrm{pp}$.

Artyushkov, E.V., Lindström, M. \& Popov, L.E., 2000: Relative sea-level changes in Baltoscandia in the Cumbrian and early Ordovician: the predominance of tectonic factors and the absence of large scale eustatic fluctuations. Tectonophysics 320, 375-407.

Asklund, B., 1928: Strandflaten på Sveriges västkust. Geologiska Föreningens i Stockholm Förhandlingar 50, 801-816.

Bergström, J., Christensen, W.K., Johansson, C. \& Norling, E., 1973: An extension of Upper Cretaceous rocks to the Swedish west coast at Särdal. Bulletin Geological Society of Denmark 22, 83-154.

Bergström, J. \& Gee, D.G., 1985: The Cambrian in Scandinavia. In D.G. Gee \& B.A. Sturt (eds.): The Caledonide Orogen - Scandinavia and Related Areas, 247-271. Chichester: John Wiley \& Sons

Blijsma, S., 1981: Fluvial sedimentation from the Fennoscandian area into the north-west European basin during the Late Cenozoic. In A.J. van Loon (ed.): Quaternary Geology: A Farewell to A.J. Wiggers - Geologie en Mijnbouw 60, 337-345.

Bonow, J.M., Japsen, P., Green, P.F., Cobbold, P.R., Pedreira, A.J., Lilletveit, R. \& Chiossi, D., 2009: Post-rift landscape development of north-east Brazil. Geological Survey of Denmark and Greenland Bulletin 17, 81-84.

Bonow, J.M., Japsen, P., Lidmar-Bergström, K., Chalmers, J.A. \& Pedersen, A.K., 2006b: Cenozoic uplift of Nuussuaq and Disko, West Greenland - elevated erosion surfaces as uplift markers of a passive margin. Geomorphology 80, 325-337.

Bonow, J.M., Japsen, P. \& Nielsen, T.F.D., 2014: High-level landscapes along the margin of southern East Greenland - a record of tectonic uplift and incision after break up in the NE Atlantic. Global and Planetary Change $116,10-29$.

Bonow, J.M., Lidmar-Bergstöm, K. \& Japsen, P., 2006a: Palaeosurfaces in central West Greenland as reference for identification of tectonic movements and estimation of erosion. Global and Planetary Change 50, 161-183.

Bonow, J.M., Lidmar-Bergström, K., Japsen, P. \& Chalmers, J.A., 2007: Elevated erosion surfaces in West Greenland and southern Norway: their significance in integrated studies of passive margin development. Norwegian Journal of Geology 87, 197-206.

Braun, G., 1935: Studien am Kjöl. Geografiska Annaler 17, 228-241.

Büdel, J., 1970: Pedimente, Rumpflächen und Rückland-Steilhänge: deren aktive und passive Rückverlegung in verschiedenen Klimaten. Zeitschrift für Geomorpgologie, Neue Folge 14, 1-57.

Clausen, O.R., Gregersen, U., Michelsen, O. \& Sorensen, J.C., 1999: Factors controlling the Cenozoic sequence development in the eastern parts of the North Sea. Journal of the Geological Society 156, 809-816.

Davis, W.M., 1899: The geographical cycle. The Geographical Journal 14, 481-504.
De Geer, S., 1910: Map of land-forms in the surroundings of the great Swedish lakes. Scale 1:500 000. With explanation. Sveriges geologiska undersökning $\mathrm{Ba} 7,1-30$.

De Geer, S., 1913: Beskrivning till översiktskarta över Södra Sveriges landformer. Sveriges geologiska undersökning Ba 9, 24 pp.

Elvhage, C. \& Lidmar-Bergström, K., 1987: Some working hypotheses on the geomorphology of sweden in the light of a new relief map. Geografiska Annaler 69, 343-358.

Erlström, M. \& Sivhed, U., 2001: Intra-cratonic dextral transtension and inversion of the southern Kattegat on the southwest margin of Baltica - Seismostratigraphy and structural development. Sveriges geologiska undersökning C 832, 33 pp.

Flodén, T., 1992: Östersjöns geologiska utveckling. In Östersjön - ett hav i förändring. Naturvetenskapliga forskningsrådets årsbok 1992, 9-22.

Gabrielson, J. \& Holland, B., 1984: Foraminiferids and their bearing on late Cretaceous sea levels in southern Sweden. Geologiska Föreningen $i$ Stockholm Förhandlingar 106, 386-387.

Green, P.F., Lidmar-Bergström, K., Japsen, P., Bonow, J.M. \& Chalmers, J.A., 2013: Stratigraphic landscape analysis, thermochronology and the episodic development of elevated, passive continental margins. Geological Survey of Denmark and Greenland Bulletin 30, 150 pp.

Högbom, A.G., 1910: Precambrian geology of Sweden. Bulletin Geological Society of Upsala 10, 1-80.

Japsen, P., Bidstrup, T. \& Lidmar-Bergström, K., 2002: Neogene uplift and erosion of southern Scandinavia induced by the rise of the South Swedish Dome. In A.G. Doré, J.A. Cartwright, M.S. Stoker, J.P. Turner \& N. White (eds.): Exhumation of the North Atlantic margin: timing, mechanisms and implications for petroleum exploration, 299-314. Geological Society, London, Special Publication 162.

Japsen, P., Bonow, J.M., Green, P.F., Chalmers, J.A. \& Lidmar-Bergström, K., 2009: Formation, uplift and dissection of planation surfaces at passive continental margins - a new approach. Earth Surface Processes and Landforms 34, 683-699.

Japsen, P., Green, P.F., Bonow, J.M. \& Erlström, M., 2016: Episodic burial and exhumation of the southern Baltic Shield: Epeirogenic uplifts during and after break-up of Pangaea. Gondwana Research 35, 357-377.

Jarvis A., Reuter, H.I., Nelson, A. \& Guevara, E., 2008: Hole-filled seamless SRTM data V4. International Centre for Tropical Agriculture(CIAT), available from https://srtm.csi.cgiar.org.

Johansson, M., Olvmo, M. \& Lidmar-Bergström, K., 2001: Inherited landforms and glacial impact of different palaeosurfaces in southwest Sweden. Geografiska Annaler 83A, 67-89.

Kleman, J., Stroeven, A.P. \& Lundqvist, J., 2008: Patterns of Quaternary ice sheet erosion and deposition in Fennoscandia and a theoretical framework for explanation. Geomorphology 97, 73-90.

Knox, R.W.O’B., Bosch, J.H.A., Rasmussen, E.S., Heilmann-Clausen, C., Hiss, M., De Lugt, I.R., Kasińksi, J., King, C., Köthe, A., Słodkowska, B., Standke, G. \& Vandenberghe, N., 2010: Cenozoic. In J.C. Doornenbal \& A.G. Stevenson (eds.): Petroleum Geological Atlas of the Southern Permian Basin Area, 211-223. EAGE Publications b.v, Houten.

Kornfält, K.-A. \& Bergström, J., 1991: Beskrivning till provisoriska, översiktliga berggrundskartan Karlskrona. Sveriges geologiska undersökning Ba 44, 33 pp.

Kornfält, K.-A. \& Larsson, K., 1987. Geological maps and cross-sections of Southern Sweden. SKB Technical Report 24. 44 pp and 44 plates.

Lidmar-Bergström, K., 1982: Pre-Quaternary geomorphological evolution in southern Fennoscandia. Sveriges geologiska undersökning C 785, 202 pp.

Lidmar-Bergström, K., 1985: Regional analysis of erosion surfaces in southern Sweden. Fennia 163, 341-346.

Lidmar-Bergström, K., 1988: Denudation surfaces of a shield area in south Sweden. Geografiska Annaler 70A, 337-350.

Lidmar-Bergström, K., 1989: Exumed Cretaceous landforms in south Sweden. Zeitschrift für Geomorphologie, Neue Folge, Supplementband $72,21-40$.

Lidmar-Bergström, K., 1991: Phanerozoic tectonics in southern Sweden. Zeitschrift für Geomorphologie, Neue Folge, Supplementband 82, 1-16.

Lidmar-Bergström, K., 1993: Denudation surfaces and tectonics in the southernmost part of the Baltic Shield. Precambrian Research 64, 337 345 . 
Lidmar-Bergström, K., 1994: Berggrundens ytformer (Morphology of the bedrock surface). In C. Fredin (ed.): Berg och jord (Geology), 44-54. Sveriges Nationalatlas, Stockholm.

Lidmar-Bergström, K., 1995: Relief and saprolites through time on the Baltic Shield. Geomorphology 12, 45-61.

Lidmar-Bergström, K., 1996: Long term morphotectonic evolution in Sweden. Geomorphology 16, 33-59.

Lidmar-Bergström, K., 1997: A long term perspective on glacial erosion. Earth surface processes and landforms. 22, 297-306.

Lidmar-Bergström, K., 1999: Uplift histories of the Scandinavian domes. In: B.J. Smith, W.B. Whalley, \& P.A. Warke (eds.): Uplift, erosion and stability, 1-7. Geological Society, London, Special publication 162.

Lidmar-Bergström, K. \& Magnusson, S.-E., 1984: Krittidslandskapet i nordöstra Skåne. Svensk geografisk årsbok 60, 165-186.

Lidmar-Bergström, K. \& Åkesson, G., 1987: Borrås skåra - a gorge of Cretaceous age? Geologiska Föreningens i Stockholm Förhandlingar 109, 327-330.

Lidmar-Bergström, K., Bonow, J.M. \& Japsen, P., 2013: Stratigraphic Landscape Analysis and geomorphological paradigms: Scandinavia as an example of Phanerozoic uplift and subsidence. Global and Planetary Change 100, 153-171.

Lidmar-Bergström, K., Olsson, S. \& Olvmo, M., 1997: Palaeosurfaces and associated saprolites in southern Sweden. In M. Widdowson (ed.): Palaeosurfaces: Recognition, Reconstruction and Environmental Interpretation, 95-124. Geological Society, London. Special publication 120.

Lidmar-Bergström, K. \& Olvmo, M., 2015: Plains, steps, hilly relief and valleys in northern Sweden - review, interpretations and implications for conclusions on Phanerozoic tectonics. Sveriges geologiska undersökning C 838, $42 \mathrm{pp}$.

Lidmar-Bergström, K., Roaldset, E., \& Olsson, S., 1999: Relief features and palaeoweathering remnants in formerly glaciated Scandinavian basement areas. In M. Thiry \& R. Simon-Coinçon (eds.): Palaeoweathering, Palaeosurfaces and Related Continental Deposits, 275-301. International Association of Sedimentologists (IAS), Special publication 27, Oxford, UK: Blackwell Publishing Ltd.

Lindström, M., (personal communication in 2000ies during work with the "Guide for geological nomenclature in Sweden") with advice to use the word peneplain for also re-exposed denudation surfaces, irrespective of their detailed forms.

Magnusson, S.-E. \& Lidmar-Bergström, K., 1983: Fossila vittringsformer från krittiden på Kjugekull. Svensk geografisk årsbok 59, 124-137.

Martinsson, A., 1958: The submarine morphology of the Baltic CambroSilurian area. The Bulletin of the Geological Institutions of the University of Uppsala XXXVIII, 11-35.

Martinsson, A., 1979: The quaternary history of the Baltic. The prequaternary substratum of the Baltic. In V. Gudelis \& L.-K. Königsson (eds.): The Quaternary History of the Baltic, 77-86. Acta Universitatis Upsaliensis Annum Quingentesimum Celebrantis: 1, Uppsala.

Mattsson, Å., 1962: Morphologische Studien in Südschweden und auf Bornholm über die nichtglaziale Felsenskulptur. Meddelanden Lunds Universitets Geografiska Institution. Avhandlingar 39, 357 pp.

Migon, P. \& Lidmar-Bergström, K., 2001: Weathering mantles and their significance for geomorphological evolution of central and northern Europe since the Mesozoic. Earth Science Reviews 56, 285-324.

Nielsen, A.T. \& Schovsbo, N.H., 2011: The lower Cambrian of Scandinavia: depositional environment, sequence stratigraphy and palaeogeography. Earth Science Reviews 107, 207-310.

Norling, E., 1994: Kontinentalsockelns berggrund (Bedrock of the Swedish continental shelf). In C. Fredin (ed.): Berg och jord (Geology), 38-43. Sveriges Nationalatlas, Stockholm.

Norling, E. \& Bergström, J. 1987: Mesozoic and Cenozoic tectonic evolution of Scania, southern Sweden. Tectonophysics 137, 7-19.
Olvmo, M., Lidmar-Bergström, K., Ericson, K. \& Bonow, J., 2005: Saprolite remnants as indicators of pre-glacial landform genesis in southeast Sweden. Geografiska Annaler 87A, 447-460.

Olvmo, M., Lidmar-Bergström, K. \& Lindberg, G., 1999: The glacial impact on an exhumed sub-Mesozoic etch surface in southwestern Sweden. Annals of Glaciology 28, 153-160.

Overeem, I., Weltje, G.J., Bishop-Kay, C. \& Kroonenberg, S.B., 2001: The late Cenozoic Eridanos delta system in the Southern North Sea Basin: a climate signal in sediment supply? Basin Research 13, 293-312.

Påsse, T., 1990: Beskrivning till jordartskartan Varberg NO. Sveriges geologiska undersökning Ae 102, 117 pp.

Penck, W., 1924: Die morphologische Analyse. Geographische Abhandlungen, Berlin. Zweite Reihe 2, 283 pp.

Phillips, J.D., 2002: Erosion, isostatic response, and the missing peneplains. Geomorphology 45, 225-241.

Rasmussen, E.S., Dybkjaer, K. \& Piasecki, S., 2010: Lithostratigraphy of the Upper Oligocene - Miocene succession in Denmark. Geological Survey of Denmark and Greenland Bulletin 22, 92 pp.

Rodhe, A., 1987. Depositional environments and lithostratigraphy of the Middle Proterozoic Almesåkra Group, southern Sweden. Sveriges geologiska undersökning Ca 69, 80 pp.

Rudberg, S., 1954. Västerbottens berggrundsmorfologi. Geographica 25, $457 \mathrm{pp}$.

Rudberg, S., 1960: Geology and geomorphology. In A. Sømme (ed.): A Geography of Norden, 27-40. Cappelen forlag, Oslo.

Rudberg, S., 1970. Geomorfologi. In. Atlas över Sverige 6. Generalstabens litografiska anstalt, Stockholm, $10 \mathrm{pp}$.

Rudberg, S., 1982: Den preglaciala stormorfologin i Sverige - en bortglömd problemdiskussion återupptagen av Karna Lidmar-Bergström. Svensk geografisk årsbok 58, 177-185.

Samuelsson. L., 1975: Palaeozoic fissure fillings and tectonism of the Göteborg area, southwestern Sweden. Sveriges geologiska undersökning C 711, 43 pp.

Samuelsson, L., 1978: Beskrivning till berggrundskartan Göteborg SO. Sveriges geologiska undersökning Af 117, 85 pp.

Samuelsson, L., 1982: Beskrivning till berggrundskartan Kungsbacka NO. Sveriges geologiska undersökning Af 124, 100 pp.

Spjeldnæs, N., 1975: Palaeogeography and Facies distibution in the Tertiary of Denkmark and Surrounding Areas. Norges geologiska undersøkels 316, 289-311.

Stephens, M.B., Wahlgren, C.-H. \& Weihed, P., 1994: Geological map of Sweden. Sveriges geologiska undersökning Ba 52.

Thomas, M.F., 1974: Tropical geomorphology, 332. Macmillan, London.

Tuuling, I. \& Flodén, T., 2016: The Baltic Klint beneath the central Baltic Sea and its comparison with the North Estonian Klint. Geomorphology $263,1-18$.

Twidale, C.R., 1976: On the survival of palaeoforms. American Journal of Science 276, 77-95.

Twidale, C.R., 1985: Old landurfaces and their implications for models of landscape evolution. Revue Geomorphologie Dynamique 34, 131-147.

Vidal, G., 1982: Den prepaleozoiska sedimentära berggrunden. In H. Wikman, Å. Bruun, B. Dahlman, \& G. Vidal (eds.): Beskrivning till berggrundskartan HJO NO, Sveriges geologiska undersökning Af 120, 52-75.

Vejbæk, O.V., 1997: Dybe strukturer i danske sedimentære bassiner. Geologisk tidsskrift, hoefte 4, 1-31.

Wikman, H. \& Bergström, J., 1987: Beskrivning till provisoriska översiktliga berggrundskaran Malmö. Sveriges geologiska undersökning Ba 40, 42 pp.

Wikman, H., Bergström, J. \& Lidmar-Bergström, K., 1983: Beskrivning till berggrundskartan Kristianstad NO. Sveriges geologiska undersökning serie Af 127, 165 pp.

Winterhalter, B., Flodén, T., Ignatius, H., Axberg, S. \& Niemistö, L., 1981: Geology of the Baltic Sea. In A. Vipio (ed.): The Baltic Sea. Elsevier Oceanography Series 30, 1-121. 